Revista de Estudios Histórico-Jurídicos

[Sección Historia de los Derechos Patrios de América]

XXXIII (Valparaíso, Chile, 2011)

[pp. 533 - 581]

\title{
Derecho INDIANO Y DERECHO PATRIO EN LAS “MEMORIAS” DE los Ministros DE JustiCiA de Chile (1839-1873)
}

\author{
['The Indianous Law and 'patrio' Law in the 'Memoirs' of the Ministers of \\ Justice of Chile (1839-1873)”]
}

\author{
Felipe Westermeyer Hernández* \\ Universidad de Chile
}

\begin{abstract}
RESUMEN
El trabajo aborda la evolución del ordenamiento jurídico chileno a través del análisis de situaciones concretas y de las problemáticas abordadas por las memorias de los ministros de justicia en el período indicado, destacando especialmente la transformación del Derecho procesal, el penal, la codificación y la relación IglesiaEstado.

\section{Palabras Clave}

Derecho Patrio - Derecho Indiano Patronato eclesiástico - Codificación.
\end{abstract}

RECibido el 22 de junio y ACEPTADO el 29 de julio de 2011

* Ayudante de Historia del Derecho en la Facultad de Derecho de la Universidad de Chile. Dirección postal: Facultad de Derecho, Universidad de Chile, Pío Nono, 1, Santiago, Chile. Correo electrónico: westermeyer.felipe@gmail.com. Agradezco la colaboración de la señora Pamela Reyes, de la Biblioteca del Congreso Nacional de Chile, gracias a quien pude obtener los documentos analizados. Asimismo a la profesora Carola Canelo, gracias a cuyos contactos todo lo anterior fue posible y a los colaboradores de cátedra señores Damián Fernández y Fabián Piedra, así como al ayudante Roberto Cerón y al profesor de Derecho administrativo de la Facultad de Derecho de la Universidad de Chile señor Cristian Román, por las oportunas observaciones que efectuaron a este trabajo. Todos los errores corren por cuenta del autor. 


\section{INTRODUCCIÓN}

Es propio de las ciencias jurídicas discutir acerca de las funciones y roles que desempeña cada organismo del Estado, así como su relación con la sociedad civil organizada y con instituciones de carácter supra-estatal. Mal que mal la delimitación de la naturaleza de un organismo implica necesariamente esclarecer con precisión cuales son sus funciones. La función hace al organismo.

Este útil ejercicio contrasta el modelo querido con la dura y porfiada realidad, lo que acarrea críticas e intenciones de reforma, reorganización o derechamente derogación de aquello que no se justifica, no se ajusta a los tiempos o no estaba contemplado en la ratio legis de la norma, si la institución tiene un origen legal.

Este ejercicio, propio de todas las ciencias jurídicas no es ajeno a la historia del Derecho. Mediante él se rompen mitos y aporta otras herramientas de juicio a viejas discusiones. Tales aportes muchas veces ayudan a entender problemáticas y conflictos que se arrastran por décadas. El trasvasije de las ideas de la elite al resto de la sociedad puede tardar décadas, hasta que como consecuencia del cambio de mentalidad, se produce un cambio la actitud y la manera de acercarse a las instituciones jurídicas. Por tal razón, los procesos de reforma jurídica por lo general son largos de asimilar y comprender ${ }^{1}$. Tal fue el caso de lo sucedido durante las primeras décadas del siglo XIX, en Chile. Bajo una solemnidad republicana y un discurso nacionalista pervivieron una serie de instituciones y formas propias del Derecho indiano y la Constitución jurisdiccional que algunos llaman del antiguo régimen. Mientras todas las constituciones buscaban ensalzar el rol del Estado nacional -en su versión ilustrada tendente a llevar a los ciudadanos a la felicidadel ordenamiento jurídico asimiló por diversas vías una serie de elementos propios del mundo indiano, mientras se esmeraba en extirparlos de manera paulatina.

Lo que puede parecer una paradoja no es sino una faceta más del cambio desde la Constitución jurisdiccional al constitucionalismo y la codificación, con la consiguiente nacionalización del Derecho y la formación de una cultura de abogados distinta a la vigente en las centurias anteriores.

Para el análisis de ese proceso las memorias emanadas del ministerio de Justicia, Culto e Instrucción Pública revisten un enorme valor. Son una fuente jurídica de carácter directo. Documentos de extensión variable y elaborados desde la necesidad de concretar tareas impostergables y de largo aliento que conferirían prosperidad y felicidad a la nación, constituyen una fuente de inapreciable valor para entender la forma en que se introdujeron nuevas instituciones jurídicas en el Derecho he-

\footnotetext{
${ }^{1}$ Hacemos este comentario teniendo en mente la discusión jurídica respecto al rol del Congreso Nacional en la historia de Chile y su relación con el Ejecutivo y con el Poder Judicial. Comparado con los otros dos poderes de la trilogía clásica del constitucionalismo de los siglos XVIII y XIX, el legislativo en Chile es mucho más nuevo, y el período en que este tuvo un "predominio" sobre el poder ejecutivo es, en general, percibido como una época de decadencia institucional. Probablemente por esas razones no ha sido estudiado con la misma acuciosidad que los otros poderes del Estado. Tampoco ha sido debidamente estudiado su rol como organismo creador de ley. Tales vacíos en la dogmática histórico-jurídica chilena importan, entre otros factores, de delimitar el rol que le corresponde al Congreso Nacional en la Constitución Politica del Estado, sus atribuciones y la legitimidad que posee ante la ciudadanía.
} 
redado de la Corona, ilustrando como pocos documentos acerca de la mutación desde un Derecho de base común a toda Latinoamérica uno de corte nacional y con una serie de elementos diferenciadores de los otros derechos patrios.

Estos documentos constituyen un testimonio fiel de la gran brecha que separaba la letra de la norma de la realidad que debían enfrentar los funcionarios públicos, jueces, ministros de los tribunales superiores, dignidades eclesiásticas, profesores y autoridades regionales de diversa índole al momento de aplicar medidas e introducir reformas que modificasen las costumbres, hábitos e instituciones vigentes en Chile. Tales memorias se refieren ante todo a las dificultades que debían enfrentar los agentes jurídicos del cambio social.

Asimismo, dan cuenta de las necesidades y falencias de las que adolecía el naciente Derecho patrio y el todavía vigente Derecho indiano.

Es inconcuso precisar que tales documentos revisten un enorme de valor jurídico, dado que a través de ellos se materializa la obligación constitucional de rendir cuenta al congreso de lo avanzado y de las problemáticas que afectan el desempeño de sus carteras. El eventual incumplimiento de esta obligación estaba contemplado como una causal que ameritaba la apertura de una acusación constitucional. El diseño del constituyente de 1833 contemplaba el control de la gestión del gobierno a través de la rendición de cuentas de los ministros de estado, no así del presidente de la república, quien, acorde con el tenor literal de la carta fundamental, no podía ser objeto de una acusación constitucional ${ }^{2}$.

Desde un punto de vista político, o mejor dicho de buen gobierno, permiten repasar el carácter proyectual de la emancipación política del Chile y la convivencia del sistema jurídico indiano y el patrio ${ }^{3}$.

\footnotetext{
${ }^{2}$ Es así como el artículo 92 de la Constitución de 1833 disponía que : "Los ministros del despacho pueden ser acusados por la Cámara de Diputados por los crimenes de traición, concusión, malversación de los fondos públicos, soborno, infracción de la Constitución, por atropellamiento de las leyes, por haber dejado estas sin ejecución, y por haber comprometido gravemente la seguridad o el honor de la Nación"

${ }^{3}$ Estas memorias se encuentran dentro de la colección Documentos Parlamentarios (= DP.), que abarca desde 1839 a 1861 (Sabtiago, Imprenta del Ferrocarril), y posteriormente, son documentos catalogados como emanados de la Imprenta Nacional, que, de acuerdo a la información obtenida en la biblioteca del Congreso Nacional, no se encontrarían compilados en ninguna colección.
} 


\section{LAS MEMORias de los ministros ANTE el Congreso Nacional:} ¿ELEMENTO PROPIO DE UN RÉGIMEN PARLAMENTARIO O PRESIDENCIAL? ${ }^{4}$

La carta fundamental de 1833 constituyó un hito en la historia constitucional latinoamericana por la influencia que proyecto en otros países de la región ${ }^{5}$, por la manera en que paulatinamente evolucionó desde un corte autoritario a otro liberal parlamentario, por su largo período de vigencia en un continente dónde la regla general es que las constituciones no se caracterizan precisamente por su larga vigencia y por el hecho de haber sido creada mediante una reforma de la anterior, así como ella misma fue abrogada por la de 1925 mediante similar proceso ${ }^{6}$.

Por esas razones, ha dado lugar a sesudos estudios que buscan explicar qué fue lo que la diferenció de otras experiencias constituyentes y cuales fueron los elementos que efectivamente posibilitaron tal cambio de régimen político desde un fuertísimo autoritarismo presidencial hasta un parlamentarismo "a la chilena", en que el Presidente debió ceñirse únicamente a un rol de jefe de estado, cuyo campo de acción era más decorativo que efectivo en cuanto jefe de gobierno.

La doctrina constitucional e histórico jurídica ha llegado, hasta ahora a algunos consensos: fueron las leyes periódicas contempladas en la Constitución de 1833 el medio de negociación mediante el cual el legislativo pasó desde una posición desmedrada frente al ejecutivo a una de absoluta primacía ${ }^{7}$; las prácticas de interpelación a los ministros constituyeron un uso que no estaba amparado

\footnotetext{
${ }^{4}$ Creemos importante hacer esta pregunta, atendido que se suele decir que el parlamentarismo como régimen de gobierno terminó el año 1925, con la promulgación de la nueva carta fundamental, lo que no es una aseveración compartida por la mayoría de la doctrina. Sostiene una posición distinta Julio Heisse González, para quien las prácticas propias del parlamentarismo pervivieron y se acrecentaron durante parte importante del período en que efectivamente estuvo vigente la Constitución de 1925. En el mismo sentido, CarrasCo DeLGADO, Sergio, Alessandri, su pensamiento constitucional: reseña de su vida pública (Santiago, Editorial Jurídica de Chile, 1987), plantea que aquel jefe de estado sostuvo hasta el final de sus días que el sistema parlamentario, como forma de regular las relaciones entre el Presidente de la República, el Congreso Nacional y los partidos políticos recién vio su fin el año 1964. Fundamenta esa postura en el hecho que muchas de las prácticas propias de ese período se ven acentuadas bajo la Constitución de 1925.

${ }^{5}$ Sobre este punto existe un luminoso y señero trabajo del profesor argentino LEVAGGI, Abelardo, La Constitución chilena de 1833 como modelo del presidencialismo argentino, en Libro de amigos dedicado al profesor emérito Italo Merello (Valparaíso, Ediciones Universitarias de Valparaíso, 2011), pp. 185 ss., donde aborda la opinión que tuvo en el continente la Constitución chilena de 1833 y la influencia en algunos puntos de la dogmática constitucional argentina.

${ }^{6}$ De hecho no son pocos los que sostienen que la única tradición constitucional existente en Chile fue la fundada por la Constitución de 1828, siendo las dos constituciones posteriores meras reformas de lo originalmente planteado por aquella. En tal sentido, véase la profusa obra de Heisse GonzÁlez, Julio, Historia de Chile: el periodo parlamentario, 1861-1925 (Santiago, Andrés Bello, 1974-1982).

${ }^{7}$ Cabe señalar que las leyes periódicas no estaban contempladas en el diseño del constituyente del año 1828, por lo que el historiador constitucional Julio Heisse en varias de sus publicaciones sostuvo que era un error tildar a la Constitución de 1833 de autoritaria, atendido que su antecesora no contempló ningún encauzamiento a las inquietudes del congreso frente al poder ejecutivo, lo que sí ocurrió con la de 1833.
} 
en ninguna disposición de ese texto, sino que más bien obedeció al estudio de publicistas europeos que describían las virtudes del sistema parlamentario y las instituciones que constituían su base ${ }^{8}$.

Si bien en este trabajo no pretendemos poner en cuestión estas premisas, si pareciera oportuno señalar que la determinación del régimen de gobierno vigente en esa carta fundamental amerita no sólo el estudio de las principales instituciones y prácticas que marcaron la relación entre el poder legislativo y el ejecutivo, sino también de los secundarios, como bien viene a ser la obligación de dar cuenta por el estado de la nación, aspecto si plasmado en el texto.

En tal sentido, las constituciones de 1828, 1833 y 1925, reconocen, en este aspecto, en el congreso el depositario de la soberanía nacional, al estar obligados a dar cuenta ante dicho organismo sobre el estado del país en las materias que a cada ministro le competían. Lo que varía entre ellas en este punto no es el órgano al cual se informa lo obrado por el gobierno y se exponen las pautas de lo que se pretende hacer en lo sucesivo, sino quien es el cuentadante.

En relación con las autoridades obligadas a dar cuenta, la evolución constitucional chilena ha ido de más a menos. La Constitución de 1828 consagraba en su artículo $84 \mathrm{~N}^{\circ}$ 4, como uno de los deberes del poder ejecutivo9: "Dar anualmente, al Congreso, luego que abra sus sesiones razón del estado de la nación en todos los ramos del Gobierno". Mas la obligación de rendir cuenta no quedaba ceñida al presidente de la república. Cada uno de los tres Ministros Secretarios de Estado contemplados en esa carta magna era responsable de los decretos que firmare y todos de aquellos que firmaren en común, debiendo, según el artículo 88 de la misma, "luego de que las cámaras abran sus sesiones anuales, dar cuenta los ministros en particular a cada una de ellas, del estado de sus ramos respectivos".

En otras palabras, la Constitución de Mora consagraba un alcance amplio a la obligación de rendir cuenta al congreso nacional por el estado y avance de los negocios, tanto desde un punto de vista general, como asimismo parcializado acorde a las materias en que se necesitare un mayor detalle.

Como se señalaba más arriba, los cambios introducidos por la comisión constituyente del año 1833, en este punto, aparte de sustituir la denominación de poder ejecutivo por el de presidente de la república, eximen al presidente de esta obligación. En materia de información de la labor desempeñada como gobierno, el presidente pasa a ser, al menos en el texto, un verdadero irresponsable. Son los ministros de estado los que responden por él, conforme al artículo 88.

Este artículo, si bien en el devenir político parece no haber tenido mayor rele-

\footnotetext{
${ }^{8}$ Inclusive no sería aventurado sostener que la adopción de estas prácticas vía costumbre, de acuerdo a los datos proporcionados por los memoristas de esa época, como el presidente de la república Arturo Alessandri Palma, era casi una ley fundamental, de acuerdo al sentido que esa expresión tiene para la doctrina francesa. Para un mayor abundamiento de esta opinión, véase: GuZmán Brito, Alejandro, El vocabulario para la idea de Constitución Política, en Revista de Estudios Histórico-Jurídicos, 24 (2002), pp. 267 ss.

${ }^{9} \mathrm{La}$ Constitución de 1828 , en su capítulo $7^{\circ}$ : Del Poder Ejecutivo, establecía que el supremo poder ejecutivo será ejercido por un ciudadano chileno de nacimiento, de edad de más de 30 años, con la denominación de "presidente de la República de Chile".
} 
vancia, si constituye una piedra importante para fundar un sistema parlamentario. Si es el ministro el que debe rendir cuenta del estado de la nación en las materias que competen a su cartera, y sólo en ellos se centra esa responsabilidad básica, pareciera que aquí se encuentra el fundamente normativo para la instauración posterior de lo que serán las llamadas interpelaciones ministeriales y votos de censura. Si entre las obligaciones de esos funcionarios estaba el cumplir la Constitución, y ellos estaban sujetos a la posibilidad de ser acusados constitucionalmente, resulta prácticamente obvio que debían concurrir a dar explicaciones cada vez que el congreso no estaba de acuerdo con alguna medida o disposición, aunque tal situación no implicase llegar a una acusación constitucional. Quien puede lo más puede lo menos. En este punto, el poder fuerte era el legislativo.

El presidente en la Constitución de 1833 es un verdadero monarca sin corona, más destinado a cumplir labores de jefe de estado que jefe de gobierno. Es otro poder él representante de la nación. Las obligaciones indicadas y las leyes periódicas permitieron ir desarmando a la presidencia de todas las facultades de las que gozó en un comienzo, en la medida en que la realidad política y social del país se complejizada y se superaban los traumas de los primeros veinte años del período patrio.

En este sentido, el diagnóstico realizado por el presidente Arturo Alessandri Palma, en su célebre conferencia dictada en el salón de honor de la Universidad de Chile, el 3 de julio de 1925, es muy asertado. En el expone los fundamentos de la nueva Constitución, refiriéndose al régimen de gobierno contemplado en la carta fundamental de 1833, señalando que la convención de reforma de la Constitución de 1828 "se encontró ante dos modelos: el régimen parlamentario o de Gabinete, clásico de Inglaterra y el Presidencial o representativo, clásico de los Estados Unidos de Norte América. El régimen parlamentario o de gabinete consiste esencialmente en que el Gabinete o Ministerio necesita para vivir y sostenerse contar con la confianza del congreso y, en consecuencia, la Cámara dispone de instrumentos adecuados para responsabilizar al Ministerio y para obligarle a abandonar su puesto cuando desaprueba su conducta o le retira su confianza. El régimen representativo establece la responsabilidad directa del presidente de la república ante el congreso, los ministros carecen de toda responsabilidad politica ante el parlamento, viven de la confianza del presidente de la república y pueden mantenerse en sus puestos mientras cuenten con su confianza"10.

Concluye el primer mandatario que el constituyente no optó claramente por ninguno de los dos sistemas.

Del análisis de los dos modelos se puede concluir que hay claramente una transacción entre ambos, no primando ninguno de ellos. El hecho que el presidente designe a los ministros de estado es propio de un sistema presidencial, y el hecho que sean los ministros los que deben rendir cuenta al congreso es propio de un sistema de gabinete, obedeciendo estas memorias a una lógica parlamentaria. La rendición de cuentas es una forma de ganarse la confianza del legislativo y no

\footnotetext{
${ }^{10}$ Actas oficiales de las sesiones celebradas por la comisión y subcomisión encargadas del estudio del proyecto de nueva Constitución Politica de la república (Santiago, Ministerio del Interior, Imprenta Universitaria, año 1925), pp. 683-710.
} 
una mera forma de control, freno y contrapeso entre los diferentes organismos constitucionales. Es una forma del régimen parlamentario o de gabinete.

Es oportuno señalar que al objeto de este artículo escapa la forma en que el legislativo recibió estas cuentas y si intervino posteriormente para su modificación, lo que quedará para otra investigación ulterior.

Por último, es dable señalar que el constituyente el año 1925, en este punto introdujo una reforma sustancial, al modificar la redacción del artículo 88, quedando los ministros obligados a rendir cuenta al Presidente de la República del estado de los asuntos vinculados a su cartera, para que sea este el que entregue esa información al congreso ${ }^{11}$.

Es decir, dentro de las reformas constitucionales del año 1925, dirigidas a fortalecer al poder ejecutivo y restar atribuciones al legislativo, se contempló una reducción de los sujetos obligados a rendir cuenta de su desempeño ante el congreso. Se entendió que de esta forma se le quitaban atribuciones al congreso. Esta modificación pasa inadvertida frente a otras de mayor relevancia, empero no debería ser preterida a la hora de buscar cuales fueron las modificaciones tendientes a fortalecer el rol del presidente de la república.

\section{Los TRibunales DE JUSTICIA COMO ELEMENTO InSUSTITUible DEL ESTADo Derecho.}

Ya desde el siglo XVIII es dable apreciar una política estatal destinada al fortalecimiento, profesionalización e independencia de los tribunales de justicia en todo el continente. En líneas generales se puede afirmar que mientras en el período indiano el esfuerzo fue la creación e implementación de nuevos tribunales letrados y especializados, será labor del período patrio en cada una de las nacientes repúblicas la regulación de sus procedimientos y asegurar una pronta administración de justicia a todas las personas.

Este proceso no alcanzó el mismo ritmo en todas las regiones del imperio español. En Chile ellas se materializaron en una nueva justicia minera y mercantil, de corte corporativo y especializada, y en la institucionalización del regente dentro de la Real Audiencia, mas no se llegó al nivel de desarrollo jurídico que vieron otras comarcas como la Nueva España, Lima o Buenos Aires.

En tal sentido, las primeras memorias dan cuenta de un diagnóstico lapidario. $\mathrm{Al}$ igual que lo sucedido con otras reformas legales, en Chile la reforma borbónica al funcionamiento e independencia de los tribunales no alcanzó a ser completamente implementada. Al menos no en el mismo grado que en otras áreas del imperio, por lo que mucho de lo sostenido en este período ya estaba claro desde antes del comienzo del movimiento juntista.

El consenso sobre la necesidad de fortalecer los tribunales y contar con un

\footnotetext{
${ }^{11}$ Así el artículo 77, inciso $1^{\circ}$ de la Constitución de 1925 dispuso: "Luego que el congreso abra sus sesiones ordinarias, deberán los ministros dar cuenta al presidente de la república del estado de la nación, en lo relativo a los negocios del departamento que cada uno tiene a su cargo, para que el presidente la dé, a su ver, al Congreso".
} 
poder judicial profesional e independiente, cuya cabeza fuese el monarca, se forjó en el siglo XVIII.

Por ese motivo, los documentos analizados dan cuenta de la proyección del rol que ocuparán en la Nación y dentro del Estado de Derecho los tribunales. Tal proyecto no presentó nada de novedoso dentro de la doctrina jurídica chilena. El diagnóstico y las principales líneas de cómo los gobiernos patrios debían configurar tan cara institución, en el detalle como vendría a ser la prueba, la inmediación, las excepciones dilatorias y las facultades de los tribunales, casi no admiten diferencias respecto a lo formulado casi veinte años antes por Juan Egaña en sus Cartas Pehuenches ${ }^{12}$.

Parte el ministro de justicia, el año 1839, señalando que las dos tareas más importantes que debe realizar el gobierno en materia legislativa son la presentación de un proyecto de ley de procedimientos, general y especial, y otro que organice el poder judicial. Agrega que desde la gran convención de 1831 hay claridad respecto a la urgencia de estas medidas, pero los problemas posteriores impidieron su pronta enmienda ${ }^{13}$. Así, parte de la base que la primera necesidad social es una pronta administración de justicia, siendo la más sólida garantía de los derechos de los pueblos. Resume el ministro de justicia de ese momento, don Mariano Egaña Fontecilla ${ }^{14}$, los problemas que presenta la administración de justicia, con la pregunta: “Quién podrá ver sin asombro tantos principios, tantas garantías judiciales, tantas disposiciones conformes a la moralidad y luces del siglo, mandadas a ejecutar por el ministerio de unas leyes que las desconocen o positivamente reprueban?"15.

Los nuevos ministros de corte y los jueces de los tribunales de primera instancia debían conocer y resolver aplicando normas que fijaban como tribunales competentes la Real Audiencia, y otros ubicados fuera del territorio nacional y que no tenían existencia legal en Chile ${ }^{16}$.

Del mismo modo, en materia procesal funcional, los mayores problemas, en su opinión, se deben a la falta de la adecuada inmediación entre el juez y las partes, a un ritualismo excesivo que sobrepasa la necesidad de garantizar la adecuada manifestación de voluntad de los intervinientes, y a la excesiva protocolización de la prueba. Todo lo anterior importaba que ir a tribunales era muy oneroso y demandaba mucho tiempo. El ministro opta por la oralidad, la inmediación del tribunal y una mayor libertad de prueba.

Los problemas anteriores, en el diagnóstico del gobierno, se veían acentuados

${ }^{12}$ Egaña, Juan, Cartas Pehuenches (Santiago, Lom Ediciones, 2001), pp. 49-61.

${ }^{13}$ En particular, se refiere a todos los trastornos administrativos y financieros acarreados por la guerra contra la Confederación Perú- Boliviana, en que si bien, en virtud de la delegación de poderes que hizo el legislativo en razón de las especiales circunstancias hubo se dictaron leyes modificatorias en materia procesal, estas, en opinión del gobierno, no invadieron las atribuciones que en razón de la Constitución, le correspondían al legislativo.

${ }^{14}$ Letrado de destacada participación en los asuntos públicos de la primera mitad del siglo XIX e hijo del ideólogo del primer tercio de esa centuria, Juan Egaña Risco.

${ }^{15}$ DP. (1831-1861), I, p. 202

${ }^{16}$ Este punto ha sido tratado por Dougnac, Antonio, Del Derecho indiano al patrio: el tránsito del magistrado Juan de Dios Vial del Río (1774-1850), en Revista Chilena de Historia del Derecho, 19 (2003-2004), p. 63 ss. 
por la inexistencia de reglas sobre competencia subjetiva y objetiva de los tribunales, por la falta de normas claras de subrogación entre ellos y por la carencia de normas de integración entre los mismos funcionarios de un tribunal, en caso de impedimento de alguno de ellos. Las reglas que se aplicaban para resolver las contiendas y cuestiones de competencia eran las indianas, que contemplaban un sistema de tribunales de carácter continental y supranacional, muy distinto del vigente en Chile. De lo anterior se derivó que no sólo la corte de apelaciones debía actuar como tribunal de segunda instancia, sino también la Corte Suprema, al verse -en la década de 1830 - impedida la primera de resolver todos los asuntos que las nuevas leyes entregaban a su conocimiento. En la práctica, en un sistema judicial de carácter jerárquico y piramidal, la corte de apelaciones y la suprema quedaban al mismo nivel, conociendo los mismos asuntos. Ambos tribunales colegiados hacían de tribunales de segunda instancia. La Corte Suprema no alcanzaba a conocer los recursos y acciones que eran de su competencia privativa.

En primera instancia, los problemas informados al congreso nacional son aún más graves. Parte de la constatación que faltan jueces letrados, por lo que los pocos que hay tienen una excesiva carga de trabajo. Eran pocos para la cantidad de asuntos en que eran competentes y para abarcar su territorio jurisdiccional.

Los tribunales de primera instancia, en aquella época, se clasificaban en superiores e inferiores. Dicha categorización se debía a la cuantía del asunto disputado o de la pena asignada al delito, al hecho que el magistrado tuviese o no la calidad de letrado y a la concurrencia en el cargo de labores de carácter judicial con otras de tipo administrativo y gubernamental.

Los tribunales de primera instancia inferiores conocían asuntos cuya cuantía no ameritaba la apelación ante corte, sino ante un tribunal de la misma jerarquía, que tuviese de titular a un magistrado con calidad de letrado. Los tribunales de primera instancia superiores se encontraban en las ciudades capitales de provincia y oficiaban de segunda instancia de lo fallado por inspectores y subdelegados ${ }^{17}$, los tribunales de primera instancia inferiores por antonomasia.

Los últimos además cumplían, como ya se dijo, funciones de carácter administrativo y gubernamental, por lo que sólo dedicaban parte de su tiempo a la administración de justicia. Su superior jerárquico en sus labores cotidianas era el respectivo intendente provincial, por lo que su independencia e imparcialidad en una serie de casos era abiertamente discutible ${ }^{18}$, Inclusive, a partir de 1851, a fin de apurar la tramitación de las causas, se obligó a los tribunales de primera instancia inferiores con asiento en localidades que carecían de juez de letras, a informar a

${ }^{17}$ Inspectores y delegados eran cargos que, de acuerdo a los artículos 115 ss. de la Constitución Politica de 1833, formaban parte del Gobierno, y eran dependientes de Intendentes y gobernadores. Los inspectores dependían de los subdelegados, teniendo los primeros a su cargo las subdelegaciones y los segundos los distritos.

${ }^{18}$ En la memoria del año 1847 el ministro de justicia acepta la incompatibilidad de funciones, pero manifiesta que nada se puede hacer para remediarlo, sino extender la ilustración, para que algún día la cantidad de personas con capacidades, conocimiento y responsabilidad permita separar las labores judiciales de las gubernativas. 
los intendentes y gobernadores de departamento del estado de tramitación de las causas que estaban conociendo, sean estas de carácter penal o civil ${ }^{19}$.

En consecuencia, ante los tribunales de primera instancia inferiores, las demoras eran tales que se sostiene la necesidad de una nueva organización judicial de todo el territorio y que los magistrados letrados de primera instancia superiores dediquen parte de su tiempo a realizar visitas a los inferiores ${ }^{20}$, a fin de dictar sentencia en el menor tiempo posible, y evitar las demoras y dilaciones ${ }^{21}$.

Otro problema del aparato judicial existente en los primeros años del período estudiado se da en materias administrativas locales. Las municipalidades son presididas por alcaldes, los que entre otras funciones, también deben cumplir algunas de carácter jurisdiccional y administrativo. Para el ministro Montt -el primero en denunciar esta problemática, en 1843- el origen democrático del cargo de alcalde posibilita que resulten electas para ese cargo personas sin las capacidades ni conocimientos para resolver los conflictos jurídicos que se encuentran dentro de su esfera de competencia. De lo anterior, el secretario de estado deduce que dichas personas, o no fallan los asuntos sometidos a su conocimiento, o lo hacían de manera contraria a lo que mandaba el ordenamiento jurídico. A ello agrega que la justicia municipal carecía de imparcialidad, al estar sujeta la elección a las tensiones propias de la contingencia electoral y estar todos los pueblos divididos en bandos políticos. El fallo dependía de a qué bando se pertenecía. En opinión del ministro, el aparato jurisdiccional municipal carecía de la independencia indispensable para la adecuada administración de justicia. Este sistema estaba muy influenciado por la contingencia política.

Del mismo modo, tal ignorancia motivaba a muchos regidores y alcaldes concientes de sus escasas luces en materia jurídica, a recusarse o a entregarle al juez local subalterno las causas que debió entrar a conocer con ocasión de su turno. Generalmente el juez local subalterno era otro regidor, el que, si no podía deshacerse del expediente, dilataba su tramitación mediante ausencia en su labor de juez, dando prioridad a los otros asuntos que la ley les encomendaba, o haciendo consultas a los jueces de letras, con lo que subían las costas procesales y demoraba

${ }^{19}$ DP. (1852-1853), IV, p. 674.

${ }^{20}$ Tales visitas constituían una subrogación del inspector o el subdelegado por el juez letrado, el que revisaba aspectos económicos del tribunal y se avocaba a conocer y resolver los asuntos pendientes de fallo ante los tribunales inferiores de primera instancia. Dicha visita tuvo un carácter transitorio, mientras se organizaban los tribunales, y muestra cuán poca conciencia hubo en los albores del Derecho patrio de la regla de la radicación de un asunto ante un determinado tribunal. Huelga señalar que las visitas a los recintos carcelarios, ya contempladas en el Derecho indiano, también son mencionadas en estas memorias, pero al seguir un curso regular hasta nuestros días y no estar sujetas a las vicisitudes del resto del Derecho procesal, no ameritan una mención especial.

${ }^{21}$ La memoria del año 1867 describe muy bien esta realidad relatando los problemas existentes en el juzgado de letras de Chillán. Ese tribunal de primera instancia superior tenía a su cargo el tribunal del departamento de San Carlos, que al estar encabezado por un juez lego, sufría enormes atrasos, por lo que ese año el tribunal de letras de Chillán era uno de los más recargados y atrasados de la república. 
la resolución de los pleitos ${ }^{22}$. A tal extremo llegó este vicio que en el año 1849 se le propone al congreso declarar franco de porte los autos que los alcaldes remitiesen en consulta o para sentencia a los jueces letrados de su provincia ${ }^{23}$.

A lo anterior se sumaba la extrema pobreza de muchas municipalidades, las que no podían costear el sueldo del regidor o el alcalde para sus labores de índole jurisdiccional. Tal fue el caso de Vallenar, dónde se llegó a proponer una contribución municipal especial, afecta al pago de los honorarios correspondientes a un juez letrado, para que ejerciera sus funciones dentro del territorio del departamento ${ }^{24}$.

Todo lo anterior se traducía en un sin fin de quejas que el gobierno trató de remediar por medio de un proyecto que obligase a que el que resultare electo fuese también el más preparado y con mayores aptitudes, y con otro proyecto de ley estableció como base del ejercicio de la jurisdicción la inamovilidad del magistrado desde ele momento de su instalación y la regla general de la competencia de la radicación de la causa una vez que el magistrado ha entrado a conocer ${ }^{25}$.

Es necesario precisar que para la mentalidad jurídica de la época, estos problemas no se solucionaban mediante leyes que introducían reformas parciales. La solución estaba dada por la dictación de códigos. El ministro Mariano Egaña fue el primero en concebir como la gran solución la promulgación en un solo acto de dos grandes leyes que se hagan cargos de los desafíos arriba indicados. Para ello, postuló que primero deben dictarse las leyes de procedimientos, toda vez que, en su opinión, la estructura, número y planta de los tribunales es funcional al sistema de enjuiciamiento y no al revés. Con tal objeto, el gobierno empezó a trabajar en un proyecto que se agrupó en tres partes: la reforma a los juicios civiles, como primera prioridad, luego la promulgación de un código procesal penal, y por último, aquella ley que organiza todos los tribunales de la nación ${ }^{26}$.

Esas reformas se basaban en leyes dictadas con anterioridad y que considera como los grandes logros del período del que se da cuenta: la ley que obliga a los magistrados a fundar sus sentencias y la ley del 29 de marzo de 1837, que precavió la eventual colusión o la criminal indulgencia de los jueces y encargados del ministerio público con los delincuentes.

Ciertamente, la codificación procesal dio lugar a muchísimas vacilaciones. De un año a otro cambiaba la prioridad entre ellas cuál discusión acerca de si estaba primero el huevo o la gallina; empero, fue la necesidad de brindar un adecuado acceso a la justicia a importantes sectores del país que no disponían de tribunales; la idea que la mejor forma de resolver los conflictos entre seres humanos es

${ }^{22}$ DP. (1847-1851), III, p. 53.

${ }^{23}$ Ibíd., p. 286.

${ }^{24}$ Ibíd.

${ }^{25}$ DP. (1842-1846), II, pp. 139-140.

${ }^{26}$ Es inconcuso señalar que esta tarea demoró bastante más de lo que los ministros Mariano Egaña y Manuel Montt jamás hubiesen imaginado, resultando este orden a la inversa: primero se legisló sobre organización de los tribunales, luego sobre juicios civiles y por último fue procedimiento penal, llevándose entre sí estas leyes alrededor de cuatro décadas y culminando esta tarea prácticamente 65 años después que los ministros la plantearan. 
el proceso y la conciencia que una justicia extremadamente onerosa no permite cumplir con los objetivos de cualquier ordenamiento jurídico, o mejor dicho, que la justicia cara no es justicia, los que dilucidaron esta discusión y orientaron la manera de sistematizar el casos reinante.

El sueño sempiterno de códigos procesales que regularan todos los aspectos de ese Derecho funcional era una promesa siempre esperada y nunca cumplida, por las dificultades propias de esa tarea ${ }^{27}$. La realidad se impuso al paradigma de la codificación.

El primer paso en esa dirección se dio en 1843, cuando, tomando conciencia que los elevados costos y las distancias impiden remediar los conflictos suscitados en sectores lejanos a Santiago, se plantea la posibilidad de dar lugar a dos nuevas cortes de apelaciones: una en La Serena y otra en Concepción. De esta forma los habitantes de las zonas norte y sur del país verían disminuir los costos de litigar ante tribunales y se reduciría la carga de trabajo de la Corte Suprema y la de la de Apelaciones. El estado de Derecho se acercaba a sectores significativos de la población y la disminución de las costas procesales constituía una mayor protección para los menesterosos. Estas cortes de apelaciones se conciben con las mismas atribuciones, competencias y jerarquía que la de Santiago.

Si bien esta ley fue de expedita aprobación, su implementación no tuvo la misma celeridad que su trámite legislativo. El gobierno tardó varios años en instalar esas cortes, justificándose en las estrecheces que padecía el erario nacional. Esos tribunales de alzada sólo pudieron empezar a funcionar el 1 de septiembre de 1849 , casi seis años después de la propuesta ministerial.

Inmediatamente, surgió el problema de la certeza jurídica. ¿Cómo evitar que de esos tribunales emane jurisprudencia contradictoria? No da lo mismo contar con uno que con tres tribunales de alzada. Por ello, conjuntamente con la creación de las dos cortes, se planteó la necesidad de contar con un recurso que permita unificar la jurisprudencia entre los máximos tribunales del país. Con ese fin, se recurrió a una solución propia del Derecho indiano: "Puede darse el caso que se dicten sentencias que, sin ser nulas, sean manifiestamente contrarias a la intención expresa de la ley. Para este sólo caso podría hacerse revivir el antiguo recurso de injusticia notoria, abolido en el día en nuestro foro, pero ligado con tales trabas y definido en términos tan precisos, que no se dejase campo alguno a los excesos a que su vaguedad dio margen en otros tiempos" 28 . Se verificó que para estos efectos el recurso de nulidad no era del todo útil: por lo tanto se dio forma a un recurso que más allá de la nulidad, garantizara la uniformidad de la jurisprudencia y resguardase la voluntad del legislador ${ }^{29}$. Años después, en 1868, se insistió en un recurso unifi-

\footnotetext{
${ }^{27}$ Desde la presentación de la primera de las leyes procesales de carácter orgánico: la ley orgánica de tribunales, hasta su aprobación, promulgación y publicación transcurrieron más de 20 años. Aparte de las dificultades inherentes a la confección de un código, sucedió que muchos de sus miembros debieron ser reemplazados en razón de l paso del tiempo y pérdida de vitalidad.

${ }^{28}$ DP. (1842-1843), II, p. 139.

${ }^{29}$ Tal idea ya muestra la paulatina recepción en el ambiente jurídico nacional de las ideas
} 
cador de jurisprudencia, pero esta vez con el nombre de recurso de casación..$^{30}$ Es decir, a raíz de un proyecto que multiplicó las cortes de apelaciones, se empezó a dar forma a un sistema nacional de recursos procesales. El ideal codificador fue sobrepasado por la fuerza de los acontecimientos, una vez más.

Situación similar ocurrió en materia probatoria. Una costumbre inveterada sólo daba el valor de plena prueba a los documentos expedidos en papel sellado, requisito que no se estaba cumpliendo en muchos litigios por lo que se dictó una ley que determinó el valor probatorio de los instrumentos que no estaban en ese papel. $^{31}$

Con ocasión de la Ley de 30 de noviembre de 1842, que autorizó la visita judicial a los tribunales de la república, se efectuó una en la provincia de Colchagua, de la que se obtuvieron algunas ideas acerca de cómo reformar las normas relativas a la pronta administración de justicia. Esas conclusiones no motivaron nuevas leyes dado que se consideró que antes había que recorrer el país entero, para de esta forma ver cuán universales eran los planteamientos recogidos desde la provincia antes dicha. No obstante, siete años después, en 1849, el ministro sostiene que la más interesante de las conclusiones aportadas por la visita a Colchagua es que la prueba en juicio debe ser pública. En Chile no se debía admitir la prueba secreta. El principio de la publicidad de la prueba facilitaría la investigación, ahorraría gastos y dilaciones y permitiría deshacerse de la prueba testimonial, en ese momento muy desprestigiada ${ }^{32}$.

De una visita posterior a la provincia de Concepción, la recomendación recogida fue establecer el equivalente jurisdiccional del abandono del procedimiento, en materia penal, ante la inactividad de las víctimas y de los encargados de perseguir a los criminales ${ }^{33}$.

Igual derrotero tomó la regulación del término de emplazamiento, cuya uniformización a todo el territorio de la república y adaptación a los nuevos caminos y medios de locomoción sucedió por una ley previa al primero de los códigos ${ }^{34}$.

Como varias de estas leyes veían torcida su aplicación ante la ignorancia de muchos magistrados legos, ya en 1847 se estableció que una de las prioridades del país debía ser contar en cada departamento con un juzgado de letras ${ }^{35}$. Sólo de esta manera se podrían evitar las sucesivas visitas, que aceleraban el trabajo judicial en unos juzgados y lo retardaban en otros.

Para cumplir con la legislación procesal no basta con tener jueces expertos, sino también que el conjunto de auxiliares en la administración de justicia sepa qué rol debe cumplir y cuales son sus obligaciones. Tal situación fue comprendida con lucidez por los gobiernos del período. En ese sentido en muchísimos pueblos el

de Montesquieu y los ilustrados, al tratar de acotar al máximo el margen de acción de los jueces en materia de sentencias, las que necesariamente debían ajustarse a la ley vigente.

${ }^{30}$ Memoria del ministro de Justicia, Culto e Instrucción Pública. Año 1868, p. 6

${ }^{31}$ DL. (1842-1846), II, p. 441-442

${ }^{32}$ DL.III (1847-1851), III, p. 286

${ }^{33}$ Ibíd., p. 286

${ }^{34}$ Ibíd., p. 54

${ }^{35}$ Ibíd., p. 52 
rol de las escribanías era fundamental. Ellos eran los peritos en Derecho en todos aquellos pueblos en que no había jueces ni abogados.

Recogiendo la necesidad de mayor personal preparado en la administración de justicia y en asuntos jurídicos en general, el año 1857 se optó por dividir las funciones de los hasta ese momento escribanos de Santiago en actuarios y escribanos de registro o, en terminología procesal contemporánea, notarios públicos. Los primeros se dedicarían a actuar como ministros de fe del juez y los segundos estarían a cargo de la custodia de archivos, el otorgamiento de instrumentos y de la mantención de los nuevos registros ${ }^{36}$. Así se propendió a la especialización de la labor del ministro de fe, ya como empleado judicial o como titular de una notaría o un registro del conservador de bienes raíces.

Dicha medida posteriormente se extendió a las jurisdicciones de Talca y Vallenar, al tribunal del Consulado, al juzgado de letras en lo civil de Valparaíso y el juzgado de letras de Ovalle ${ }^{37}$.

El año 1860 dicha división de las funciones que originalmente competían sólo a Santiago se hizo extensiva a los territorios jurisdiccionales de la corte de apelaciones de Concepción y al tribunal del consulado de Valparaíso.

Valparaíso, por su enorme tráfico y comercio, fue el escenario dónde partieron varias de las modificaciones más importantes a nuestro sistema procesal. Ese fue el caso del cobro de los derechos que les correspondías a los receptores para la realización de diversas diligencias, principalmente por la notificación de las demandas. Para la fijación de estos derechos se consideraba al barrio El Almendral y a muchos de los cerros profusamente habitados e inclusive cercanos a los tribunales como extramuros de la ciudad, lo que permitía cobrar el doble de los derechos que si se estuviese dentro de los límites bajo los cuales se había elaborado la tarifa vigente en ese momento. Una manera de acercar la administración de justicia a la población es precisamente abaratar sus costos y que el costo de ciertos trámites se ajuste a la realidad.

Para solucionar tal flagelo se formó una comisión compuesta por los cuatro jueces letrados del puerto y el intendente, que elaboró un nuevo plano de la ciudad, siendo este sancionado por el gobierno mediante decreto de 6 de abril del año $1865^{38}$.

Dicho problema se repetía en varias otras localidades del país. De hecho, en Santiago ocurría similar situación respecto de los barrios ubicados al norte del río Mapocho y de la Cañada al sur, debido a que el plano que regía los cobros de los derechos de los ministros de fe databa del siglo XVIII.

El ministerio de justicia se dirigió a la Corte de Apelaciones de Santiago, a fin de actualizar los límites de la ciudad, para efectos de volver tasar los derechos de los ministros de fe e incorporar las nuevas zonas pobladas a los límites urbanos.

Pese a que el tribunal de alzada consideró urgente la medida, no se sintió facultado para adoptar una medida de esa envergadura ${ }^{39}$.

\footnotetext{
${ }^{36}$ DL. V. (1857-1858), V, p. 59.

${ }^{37}$ DL. (1861), IX, p. 315

${ }^{38}$ Memoria del ministros de Justicia, Culto e Instrucción Pública, Año 1865, p. 11.

${ }^{39}$ Ibíd., p. 12-13.
} 
La solución pasó entonces a manos del legislativo, que terminó dictando una ley delegatoria de facultades en el presidente de la república, a fin que fuese este el que fijase el monto de los aranceles y los límites dentro de los cuales sólo podían cobrarse los derechos ordinarios establecidos en esas tablas. Un aspecto a destacar de esta ley es que fue aprobada previo informe de las Cortes de Apelaciones de La Serena, Santiago y Concepción y de la Corte Suprema ${ }^{40}$.

Al parecer, esa ley no tuvo la relevancia pensada, por lo que, en los años siguientes varios tribunales crearon cargos de tasadores de costas y liquidadores, a fin de hacer más fácil la administración de justicia y no entrabar las sentencias definitivas en este tipo de discusiones ${ }^{41}$.

En el mismo sentido, cabe destacar que la creación de la planta de los tribunales no estuvo exenta de complicaciones. La permanente dilación en la resolución de las causas, motivó a crear dentro de los tribunales de menor cuantía un funcionario especial, un agente del tribunal. Ese auxiliar estaba encargado de practicar las diligencias esenciales decretadas por los jueces, y se pagaba con una exigua remuneración y un arancel fijado por ley, en que se tasaba cada una de las diligencias y trámites a efectuar.

Por ende, a poco de haber sido creado, no dejó de llamar la atención del gobierno el interés que se generaba cada vez que se abría un puesto de este tipo en alguna ciudad. Inmediatamente se sospechó que no se estaban respetando los aranceles legales, por lo que el gobierno encargó una serie de informes para determinar qué uso se había generado en tribunales. Este agente se había transformado en un intermediario entre el peticionario y el tribunal, lo que no agradó al gobierno, en vista que alejaba del pueblo al magistrado. El gobierno inmediatamente dictó las providencias para volver a regular el rol que a esa persona le correspondía dentro del aparato judicial ${ }^{42}$.

La necesidad de acabar con las largas esperas y la excesiva dilación en los plazos de tribunales hicieron que el ejecutivo y el legislativo optaran por mantener ese cargo. Se prefirió la celeridad a la inmediación entre el juez y los peticionarios. Esta opción se materializó en la posterior apertura de nuevos puestos para esos agentes en las ciudades de La Serena, Copiapó, Quillota, Los Andes, Melipilla, Cauquenes, Constitución, San Fernando, Talcahuano, Concepción, Los Angeles y Llanquihue. Para evitar la reproducción de los vicios oportunamente denunciados, paralelamente se proveyeron nuevas plazas para procuradores que se hicieran cargo de velar por una recta y adecuada tramitación de los autos, evitando cualquier tipo de cobro excesivo o ajeno al proceso ${ }^{43}$.

Ya a comienzos de la década de 1860, había dos ciudades que tenían más de un tribunal competente en el mismo territorio: Santiago y Valparaíso. Con ello surgió el clásico problema de cómo se distribuyen las causas de manera equitativa.

Ese problema se suscitó primero en el puerto. Entre los cuatro juzgados hubo una desproporción de las causas que cada uno de ellos conocía. Evidentemente,

\footnotetext{
${ }^{40}$ Memoria del ministro de Justicia, Culto e Instrucción Pública, Año 1866, pp. 8-9

${ }^{41}$ Ibíd., p. 11

${ }^{42}$ DL. (1854-1856), V, pp. 300-301.

${ }^{43}$ DL. (1860), VIII, pp. 72-73.
} 
aquel tribunal que más causas conocía, más tardaba en fallarlas. Por eso la primera solución que decretar una visita de un ministro de la Corte de Apelaciones de Santiago, con la consiguiente aceleración de la tramitación en ese tribunal y las dificultades inherentes a la subrogación de ese ministro en la Corte de Apelaciones. Se tapaba un forado abriendo otro. Por ello, se presentó un proyecto de ley para fijar un sistema de distribución de causas, que radicó los tribunales del crimen el conocimiento y fallo de todas las causas de hacienda que se iniciaren en los departamentos de Valparaíso y Casablanca y , paralelamente, todo juicio de concurso quedó radicado en el juez de comercio del puerto ${ }^{44}$.

Desgraciadamente, en las décadas estudiadas comenzó ha esgrimirse por parte del ejecutivo un argumento permanente para evitar que los tribunales llegaran demasiado lejos: la permanente carencia de recursos por parte del erario o su focalización en otras áreas más importantes. De esa manera se podía evitar un despegue del poder judicial frente al poder político. Es así como se comenzó a exigir un cierto orden y economización de recursos por parte de los tribunales, ya que costaban demasiados recursos al erario nacional.

Para tal efecto, la primera medida fue centrar en el secretario del tribunal toda la responsabilidad por los bienes que estaban en sus dependencias y por los documentos entregados a su custodia. Esta idea se concretó mediante la obligación de incorporar a la documentación permanente y obligatoria de todo tribunal del país un inventario. Por medio de ese instrumento, sólo se proporcionaban recursos para recuperar aquello que se había perdido ${ }^{45}$.

Como último comentario sobre este punto, de todo lo expuesto pareciera inconcuso que, más allá del tenor literal de la Constitución de 1833, el poder judicial como un poder autónomo e independiente en los primeros años del período estudiado no pasó de ser una utopía.

Sin embargo, a poco andar comenzaron a dictarse las leyes necesarias para ordenar las funciones y labores de cada tribunal. Mediante una serie de cortas leyes se procuró que la judicatura tuviera un mínimo de organización. El Derecho patrio consagró por medio de sus vías formales las normas básicas del Derecho procesal. Los códigos podían esperar, como de hecho lo hicieron. Las instituciones no pueden esperar la existencia de un cuerpo legal que delimite sus funciones. En este caso, en virtud de leyes y de las facultades económicas de los tribunales superiores de justicia se comenzó a dar forma al Derecho procesal chileno. Salvo contadas excepciones, como la división de las funciones del ministro de fe en las

${ }^{44}$ Memoria del ministro de Justicia, Culto e Instrucción Pública, Año 1866, p. 12. La ley a la que se refiere fue promulgada el 19 de julio de 1865, y contiene escuetos dos artículos. En el primero se establece la competencia privativa del juez de comercio de Valparaíso en casos de concurso y en el segundo las causas de hacienda se radican en los tribunales del crimen del puerto. En este artículo segundo, en su inciso penúltimo, se hace una referencia al sistema de distribución del trabajo entre los tribunales, haciendo una mención al sistema de turno: "Los dos jueces de letras en lo criminal seguirán para el conocimiento de las expresadas causas el mismo turno establecido para el de las criminales". El texto completo se ve en ANGUITA, Ricardo, Leyes promulgadas en Chile (Santiago, Imprenta, Litografía y Encuadernación Barcelona, 1912), II: $1855-1886$, p. 199.

${ }^{45}$ Memoria del ministros de Justicia, Culto e Instrucción Pública, Año 1866, p. 11 
de actuario judicial o notario, lo que hay es una actualización de las sempiternas normas del Derecho procesal a la nueva realidad política, económica, social y administrativa y el comienzo de la nacionalización del Derecho procesal ${ }^{46}$. Se deja atrás un Derecho de juristas, como era en materia procesal el Derecho indiano y se pasa a un sistema jurídico basado en la ley, como fuente suprema de Derecho.

Los aportes en materia de dogmática jurídica fueron muy pocos; no obstante dictarse normas cuyo fin era combatir los vicios surgidos al alero de la legislación indiana en materia de tramitación y resolución de causas.

\section{Las “Leyes Marianas”}

Si bien las leyes marianas abarcaron un conjunto de temas que no son abordados por las memorias estudiadas, oportuno es tener presente qué dijeron estos documentos sobre las normas procesales, aparte de lo ya referido respecto a la posible codificación procesal.

La memoria de 1839 hace una reivindicación de las normas dictadas al alero de las facultades extraordinarias concedidas al Presidente de la República con ocasión del conflicto bélico con la Confederación Peruano-Boliviana. Hace una defensa de la modificación del ordenamiento jurídico por la vía de las facultades extraordinarias concedidas al ejecutivo con ocasión del estado de excepción constitucional suscitado por el conflicto con la Confederación Perú-Boliviana ${ }^{47}$.

A tal grado importa lo anterior, que reivindica la legitimidad de las medidas haciendo alarde de la enorme circunspección de las autoridades del momento, al legislar y reformar sólo aquellos puntos cuya solución demandaba suma urgencia. Contando con las facultades, no se quiso cercenar al congreso nacional de aquellas labores que la Constitución le entrega.

Lo anterior se traduce en que en materia procesal sólo se entraron a regular aspectos específicos que en ese momento generaban los más importantes vicios en materia de administración de justicia: se limitó la amplia facultad concedida a las partes por el reglamento de justicia de 1824 , en materia de recusación de los jueces. Ahora sólo podría recusar al magistrado por causa legal debidamente probada, y la interposición de este incidente perdía su carácter dilatorio. Pasaba a tramitarse en cuaderno separado y no tenía la calidad de incidente de previo y especial pronunciamiento. La recusación perdió su carácter dilatorio y pasó a ser un derecho de las partes de carácter restringido.

${ }^{46}$ Se habla del comienzo de la nacionalización del Derecho procesal pues hubo normas que, si bien fueron dictadas en Chile, corresponden al período indiano, como es el auto acordado de tramitación de causas del crimen del año 1767, del oidor José Perfecto de Salas, que estuvo vigente en Chile hasta la publicación del Código de Procedimiento Penal en 1906. Al respecto, véase: Westermeyer Hernández, Felipe, Notas para un estudio de la evolución de la judicatura en Revista de Derecho y Humanidades, 9 (2002-2003), pp. 249-260.

${ }^{47} \mathrm{La}$ legislación mediante delegación de facultades por parte del legislativo constituyó un uso en el Derecho público chileno cuyo primer antecedente son estas leyes. Bajo el imperio de la Constitución de 1925 la delegación de las facultades legislativas pasará a ser una costumbre o práctica constitucional tolerada por todos los actores jurídicos y constitucionales, siendo profusamente regulada recién en la Constitución de 1980. 
La recusación se había convertido en el principal medio para burlar las acciones ante tribunales. En una sociedad tan pequeña era casi imposible que no hubiese vínculos entre magistrados, abogados y peticionarios, por lo que cualquier figura que le diera un carácter extensivo, de Derecho absoluto, entrampaba cualquier acción ante tribunales. Era el mejor ardid de la mala fe procesal.

Otra de las leyes marianas de relevancia procesal mencionada en la aludida memoria de 1839 es aquella que establece la obligación de los jueces de fundar sus sentencias. Esta norma, denominada de fundamentación de las sentencias, a través del decreto de 2 de febrero de 1837, se limitó a señalar que toda sentencia debía ser fundada breve y sencillamente, reduciéndose el fundamento a señalar las cuestiones de Derecho o hecho sobre las que recae la sentencia y hacer referencia a las leyes que les sean aplicables, sin comentarios ni otras explicaciones.

Sobre esta norma no hay mayores referencias, pero ameritan por lo menos un comentario. Pareciera ser que esta ley constituye un hito en la adopción del positivismo jurídico como sistema que regula la relación entre la legislación y el tribunal. Su tenor literal ya es indicativo del rumbo que adoptará el Derecho nacional en el Código Civil de Bello, optando un sistema jurídico que hará a la ley sinónimo de Derecho, no dejando espacio a los tribunales para que puedan desarrollar doctrina o recurrir a otras fuentes formales de Derecho ${ }^{48}$.

Por esta vía se concreta un ordenamiento jurídico de corte legal, superando el Derecho de juristas propio del mundo indiano.

Otra de las leyes marianas mencionada es aquella que limita el arbitrio de los tribunales. Se busca la exacta aplicación de las leyes penales, por duras que sean las penas. Se considera que "no se preveía de suficiente remedio para los casos en que el juez no hubiese aplicado el castigo debido, i la necesidad de velar por la exacta aplicación de las leyes penales" ${ }^{39}$. Para tal efecto se establece que se entiende por denegación de justicia, sus penas y el caso en que el juez comete ese delito ${ }^{50}$.

\footnotetext{
${ }^{48}$ Sobre esta reforma: Merello Arecco, Italo, La ley mariana de fundamentación de sentencias frente a la clemencia judicial en materia penal, en Revista de Estudios Histórico Jurídicos, 8 (1983), pp. 71-98. El autor señala que el origen de esta norma es el principio ilustrado de obligar a los jueces a fundamentar sus fallos en razón de ser un acto fundado en la ley. No discutimos esta afirmación, mas nos merece un pequeño comentario. Del tenor literal de la norma se desprende que su concepto de fundamentación es más bien precario, centrado la aplicación automática de silogismo, desatendiendo la casuística de la que, en definitiva, la filosofía de la escuela de la exégesis no pudo hacerse cargo. Esta norma sería el primer paso a la adopción de un sistema legal en que el juez sólo es la boca de la ley, en que la jurisprudencia de los tribunales se ve postergada como fuente del Derecho. Decimos que es el primer paso pues el ministro que da cuenta de esta memoria es el redactor de la ley, y en su ideario jurídico contempló otras fuentes del Derecho, en subsidio de esta, como los principios generales del Derecho natural, la jurisprudencia de los tribunales, la analogía, la doctrina de los juristas más reputados y el espíritu general de la legislación. Lo importante es que introduce un nuevo medio de control del ejercicio de la labor jurisdiccional. Al respecto, véase: BEATTIE Cruz, Carolina, Egaña y la codificación procesal en Chile. Las instituciones de los fueros, implicancias y recusaciones, conciliación y fundamentación de las sentencias (Memoria de licenciado, Universidad de Chile, 2009, inédita).

${ }^{49}$ DL. (1831-1841), I, p. 204.

${ }^{50}$ Una disposición similar no se consagró en el artículo 23 del Código Civil de Bello, que
} 
Claramente, la reivindicación que hace de estas leyes el ministro, aparte de referirse a la legitimidad del medio usado, buscan dar mayor certeza jurídica mediante el angostamiento del ámbito de interpretación de los tribunales. Es en este punto dónde se aprecia el mayor quiebre con la cultura jurídica indiana, cuyos tribunales gozaban de la mayor amplitud y su concepto de justicia se basaba en la apreciación del caso concreto.

Con los antecedentes proporcionados en estas memorias, no es posible afirmar cuan importantes fueron en definitiva estas leyes en la formación del Derecho patrio. No obstante, la defensa que se hace del medio que se usó para dictarlas y la explicitación de las normas indicadas induce a que fueron criticadas en el medio jurídico y que violentaron, en alguna medida, la mentalidad jurídica de la época, tanto en materia del rol de los tribunales comoen cuanto a las fuentes del Derecho. En consecuencia, queda en evidencia cuáles serán las opciones del ejecutivo en cuanto a dónde se rompe con la legislación hispana e indiana. Para fortalecer el Derecho nacional se optó por limitar las atribuciones del juez y obligarlo a fallar conforme a la ley vigente. Se coarta la interpretación y se limita a los tribunales, imbuídos aún por el Derecho indiano, a fin de cultivar el advenimiento de los códigos y una mentalidad jurídica legalista.

\section{LA ADMINISTRACIÓN DE JUSTICIA: ¿GARANTÍA CONSTITUCIONAL O RESABIO MONÁRQUICO?}

Del análisis del tenor literal de estas memorias, no deja de llamar la atención la reflexión hecha por el ministro con ocasión de la dictación de las leyes antes mencionadas: "Para llenar el deber que incumbe al Presidente de la República de velar sobre la pronta y cumplida administración de justicia y sobre la conducta ministerial de los jueces [...] se promulgaron las leyes [...]" 51 .

Si bien en esa época el carácter de texto vivo y vinculante de la Constitución política era muy distinto del que se arrastra desde las últimas décadas del siglo XX, es dable señalar que las memorias, al plasmar este comentario, se limitan a reflejar el texto. En efecto, el artículo 82 de la Constitución Política de 1833 contempla entre las atribuciones del Presidente de la República velar por la pronta y cumplida administración de justicia y por la conducta ministerial de los jueces.

Es decir, la administración de justicia no es garantizada directamente por la Constitución, sino por el presidente de la República. Es una atribución del primer mandatario cautelar este pilar del estado de Derecho. Cabe entonces preguntarse quién es el que dirige el poder judicial. ¿Hasta dónde llegaban las facultades disciplinarias del máximo tribunal del país si es otro poder del estado el encargado de velar por la adecuada conducta de los magistrados? Una disposición de ese tipo ¿es compatible con la idea de poderes independientes entre sí, tan cara al constitucionalismo moderno? ¿`o es más bien otra manifestación del siglo XVIII,

ordena estar al "genuino sentido" de la ley, no a su letra.

${ }^{51}$ DL. (1831-1841), I, pp. 205-206. 
en virtud de la cual el Supremo magistrado es el monarca, ahora revestido de formalidades republicanas, bajo el título de presidente de la república?

Del tenor literal de la carta fundamental se desprende que la convención de 1831 optó por entregar este punto al legislador. La función se radica preferentemente en la figura del presidente de la República, pero se da la posibilidad que el legislador altere posteriormente la relación de atribuciones entre el jefe de estado y los tribunales. Al igual que en otras áreas del Derecho público chileno, la Constitución de 1833 tenía un acentuado énfasis en la figura del presidente de la república, que podía ser posteriormente matizado mediante una válvula de escape, que posibilitaba un fortalecimiento del poder judicial: el artículo 113. Este disponía: "Habrá en la República una magistratura a cuyo cargo esté la superintendencia directiva, correccional y económica sobre todos los tribunales y juzgados de la nación, con arreglo a la ley que determine su organización y atribuciones".

El tenor literal de la Constitución claramente muestra cuál fue la opción del constituyente y cuán arraigado estaba en nuestro imaginario jurídico el espíritu indiano y los ideales de la Constitución jurisdiccional. Es obligación del monarca mantener a los súbditos en paz y justicia y esa obligación es asumida por la Constitución de 1833 como una mera atribución del presidente de la República. El garante del acceso a la administración de justicia es el presidente de la república, no los tribunales ni el legislativo. Al menos en este punto, el pensamiento republicano no impregnó el texto constitucional.

Refuerza lo anterior el hecho que, al igual que en otras materias, el modelo que probablemente se tuvo en vista para redactar esta disposición fue la Constitución de Cádiz de 1812. Esa carta magna, al tratar las prerrogativas del rey, en su artículo 171, numeral cuarto, señala que entre las facultades del monarca esta "cuidar de que en todo el reino se administre pronta y cumplidamente la justicia" 52 .

En un primer tiempo, tal idea de corte monárquica no quedó en las meras declaraciones. En virtud de esa atribución, durante los años del primer conflicto republicano con Perú y Bolivia, el presidente de la república, mediante ley, dictó un procedimiento especial para las visitas de los jueces letrados y se facultó al ministro de justicia para practicarlas por su cuenta en los casos en que lo estimare conveniente. En otras palabras, el presidente de la república estaba facultado para intervenir en materias jurisdiccionales, fijando los ritmos y prioridades de los tribunales mediante un mero acto administrativo. Bastaba delegar en un funcionario la labor de revisar el trabajo de cada tribunal para determinar el sentido y alcance de un fallo y para fijar las prioridades de los tribunales en materia judicial. Qué asuntos se verán de manera preferente, qué asuntos de manera agregada y qué asuntos deben quedar pendientes de fallo.

Sin embargo, al menos el gobierno del presidente Manuel Bulnes en este

\footnotetext{
${ }^{52}$ Si bien la influencia de la Constitución de Cádiz en el constitucionalismo chileno es un tema que recién se está comenzando a tratar, del análisis comparado de los textos de 1822, 1828 y 1833 se desprende que hay un grado de influencia importante, más allá del que la historiografía tradicional ha reconocido. Al respecto, véase: BARRIENTOS GRANDóN, Javier, La Constitución de Cádiz en Chile, en Escudero, José Antonio (coordinador), Cortes y Constitución de Cádiz 200 años (Madrid, Fundación Rafael del Pino, Espasa Libros, 2011), III, pp. 674-699.
} 
punto optó por la prudencia. Consideró que los más autorizados para efectuar esas visitas eran los mismos jueces, o que en su defecto, ellos debían acompañar al visitador. A su vez, esa política dejaba en evidencia otro problema. Una de las posibles consecuencias de la visita podía ser la necesidad de remover al personal del tribunal que abiertamente tenía un desempeño deficiente, lo que acrecentaba la sensación de desmedro del poder judicial, toda vez que aún no había jueces que tuviesen la propiedad de su cargo $^{53}$.

El año 1844, el gran avance que el ministro de justicia del momento, Manuel Montt, expone al congreso en esta materia, es la promulgación de la ley que regula el nombramiento de los jueces, confiriendo a varios de ellos la propiedad en el oficio.

Si bien ello habría ameritado la aplicación de las normas sobre visitas del ministerio de justicia, ya que el defecto que inhibió al gobierno en un primer momento estaba superado, a poco andar el legislador, mediante la discusión de la ley orgánica cambió el sentido y alcance de esta normativa constitucional. Ya en el año 1840, con ocasión de la exposición del programa legislativo de creación y sistematización del Derecho procesal patrio, el ejecutivo reivindicó la autonomía normativa, funcional y económica del poder judicial. Este fue el primer paso hacia la independencia de los tribunales. Se optó porque la independencia y autonomía del poder judicial no sólo fuese una idea presente en la doctrina conocida por los hombres de Derecho, sino también que fuese un principio que informara la legislación. Este fue el primer paso de un largo camino que recién comenzaba.

Para tales efectos, se partió de la premisa que era necesario abolir la mayor cantidad de fueros ${ }^{54}$, clasificando los litigios única y exclusivamente en razón de su cuantía. Luego se debían detallar las funciones y roles de cada juzgado, los cargos que debían contemplar las plantas del poder judicial y dividir el territorio nacional en distritos jurisdiccionales. Por último, se establece la obligación de los jueces letrados, sean de los tribunales de primera instancia o de ministros de corte, de realizar visitas por su territorio, dictando las sentencias en los litigios pendientes de fallo o acelerando la sustanciación de los mismos, en base a las normas de procedimiento fijadas por el legislador. Es decir, la visita únicamente la podían efectuar magistrados integrantes del poder judicial, no letrados designados por el ministro de justicia. En otras palabras, la administración de justicia, acorde con este proyecto, pasaba a ser una carga de los letrados que ejercían el oficio de jueces.

Esta nueva visita, mediante ley dictada el año 1850, fue estatuida como parte del oficio del magistrado de los tribunales superiores de justicia. Para tales efectos,

${ }^{53}$ DL. (1842-1846), II, p. 440.

${ }^{54}$ Así la memoria del año 1843 , sostiene que debe eliminarse el fuero del que gozan los funcionarios públicos en las causas civiles, ya que perjudica a todos los que buscan la vindicación de sus derechos. Ese fuero consistía en que los funcionarios que de él gozaban podían solicitar que sus asuntos los conociera directamente la Corte Suprema, con lo que ese tribunal pasaba a conocer en primera y segunda instancia de la misma causa, generándose una integración con jueces de primer a instancia en caso que una de las partes sufriere un agravio con la sentencia emanada de la Suprema en primera instancia [DL. (1842-1846), II, p. 444]. 
se ideó un sistema de turnos para que esta carga del oficio fuese repartida entre todos los ministros. De esta forma, la visita pasaba a ser prerrogativa exclusiva de los tribunales superiores. Un paso importante hacia la autonomía del poder judicial, atendido que no da lo mismo que las prioridades al momento de conocer los conflictos las fije un superior jerárquico del mismo oficio que un externo. También es inconcuso que no es lo mismo que un fallo lo emita un juez que maneja la jurisprudencia de los tribunales superiores y conoce en segunda instancia de los problemas que se dan en su territorio jurisdiccional a que esa sentencia emane de un tercero que no conoce las limitaciones propias del rol que se debe cumplir ${ }^{55}$. El proyecto marcó la adopción de las ideas del constitucionalismo moderno y la superación, en la letra de la ley, de aquel resabio monárquico que consagraba al presidente de la República como garante de la administración de justicia. El presidente de la República adquiría de esta forma un carácter más acorde con el rol del jefe de estado y de gobierno en el estado constitucional decimonónico.

Ese proyecto buscó la exaltación del rol del juez. En lugar de un garante había que dotar al ordenamiento jurídico de una nueva figura: el magistrado. El magistrado como máxima expresión de la administración de justicia y como funcionario al servicio del pueblo y la comunidad. Para lograrlo, fijó los deberes generales del juez y se fijó un estatuto de responsabilidad ministerial y las acciones para hacerla efectiva. Se dispuso un sistema de nombramientos, sustituciones y subrogaciones, se les confiere un sueldo acorde con un trabajo que demandaba mucho tiempo y estimulase a las personas más preparadas y honestas a optar por ese rol, agregando un montepío para la viuda y los hijos de aquel que hubiese destacado por su trabajo y calidad profesional y se organiza la superintendencia directiva, correccional y económica, que queda en manos de la Corte Suprema ${ }^{56}$. Dicha superintendencia se fija en aras del mandato dispuesto en el artículo 113, y consistía en la vigilancia de la conducta de los magistrados, la revisión del despacho de los juzgados, el rol de los subalternos en los tribunales, la reprensión de las faltas y abusos cometidos con ocasión de la administración de justicia.

Para ello en memorias posteriores se insistió en la necesidad de contar con un estatuto especial para el juez y el ministerio público ${ }^{57}$, fundiéndose en este último instituciones propias de la época anterior como el defensor de obras pías y las defensorías de menores ${ }^{58}$.

El legislador tomó como propia esta exaltación del rol del juez a tal punto, que varias de estas ideas fueron recogidas para casos particulares antes que el proyecto

${ }^{55}$ DL. (1852-1853), IV, p. 313.

${ }^{56}$ Es importante tener presente que la memoria no emplea este vocablo. Se limita a repetir la expresión de la Constitución "Tribunal Supremo", no obstante en ese momento ya llevaba años de existencia la Corte Suprema.

57DL. (1861), IX, p. 311.

${ }^{58}$ El fundamento es que las defensorías aludidas se pagaban con cargo a los mismos menores y establecimientos piadosos, siendo que la situación del menor y de las obras que incentivaban el fervor religiosos y la ayuda a terceros mediante la iglesia u otras agrupaciones religiosas católicas era asuntos que importaban a la sociedad en su conjunto y por ello debían pasar a ser representadas por un organismo encargado de velar por los intereses colectivos y pagado con cargo al erario nacional. 
fuese sancionado. Es así como el año 1854 se aprobó un aumento de sueldo para los ministros de las cortes de apelaciones de La Serena y Concepción, y para los jueces letrados del departamento de Atacama, como una forma de compensar su lejanía de la capital ${ }^{59}$.

Como el trámite de este proyecto fue largo, en el ínterin el ejecutivo intervino en los tribunales inferiores de una manera menos invasiva, haciendo valer las atribuciones que sobre ellos poseía en razón de la doble dependencia de estos. Así, procedió a uniformar criterios de tramitación verbal y escrita mediante formularios que distribuyó entre inspectores y subdelegados.

Asimismo, este nuevo ideal de justicia se cimentaba una mayor accesibilidad de las personas a los tribunales. Tal necesidad admite varias aristas. Una de las más importantes fue crear paulatinamente nuevos tribunales superiores de primera instancia a la largo del país. Es así como a partir de 1850 se empiezan a estatuir tribunales en diversos departamentos de la república. Se crean segundos tribunales letrados en Valparaíso y Copiapó, en razón de la abultada carga de trabajo que tenían. Asimismo, se dotó de un juzgado de letras a las localidades de Arauco, Curicó, Illapel, Vallenar, Freirina, Combarbalá y Rancagua.

El año 1857, en virtud de ley promulgada el 13 de julio de ese año, se crearon los tribunales de letras de Ovalle y Linares y en 1859 correspondió tal privilegio a los departamentos de Quillota, Parral y Caupolican y ese mismo año comienzan a crearse los primeros juzgados de letras con competencia especial en materia penal, los que se ubicaron en la ciudad de Valparaíso y tenían a su cargo la investigación, resolución y sanción de los delitos leves. Por ley de 25 de junio de 1860 se creó otro juzgado de letras en Los Andes.

También en esa década se propendió a la especialización dentro de los tribunales, dotando a los del crimen de Santiago y Valparaíso de secretarios especiales rentados y de un juez de Derecho al tribunal del Consulado.

También en este período se denuncia por primera vez una de las mayores limitaciones a la administración de justicia en cuanto Derecho y garantía: la falta de imperio de los tribunales. Por ello ya en 1867 se propone la organización de una policía dependiente de los juzgados del crimen, a las que los jueces competentes puedan dar órdenes sin tener que pasar por el cedazo de la autoridad administrativa $^{60}$.

\section{Protección a Las Personas}

Este punto es tratado por los documentos en estudio a raíz de la situación carcelaria y el Derecho penal. Proteger a las víctimas del delito y recuperar a los delincuentes a la vida social fue el gran objetivo de este período. El arquetipo de la pena privativa de libertad es ser a la vez un escarmiento y un medio de civilización de la persona del delincuente, a fin que salga del presidio con un grado mayor de educación y con la convicción, moral y religiosa, que debía enmendar

\footnotetext{
${ }^{59}$ DL. (1854-1856), IV, p. 93

${ }^{60}$ Memoria del ministro de Justicia, Culto e Instrucción Pública, Año 1867, p. 11.
} 
su camino. Es el ideal de esta época recuperar al delincuente para la sociedad. La meta es su readaptación.

Los documentos estudiados dan cuenta de un objetivo de política criminal orientado a garantizar niveles de seguridad pública altos, que permitan el adecuado desarrollo de actividades económicas.

Asimismo, hay consenso en que, para el logro de tales objetivos, hay falencias a nivel normativo y penitenciario.

Normas que atentan contra los derechos básicos que proclamó la ilustración y que paralelamente consagraban una cantidad de formalismos que impedían actuar con celeridad en la investigación y punición de los actos antijurídicos, junto a un sistema carcelario que no impedía la fuga del reo ni la rehabilitación de aquel que seguía cumpliendo su condena, constituyeron un gran problema para el ministerio de justicia. Un buen ejemplo de ello era la pena de azotes. Para el ejecutivo era una pena ineficaz, que además tenía efectos perniciosos: degrada profundamente el alma del que la sufre ${ }^{61}$. Es en el área del Derecho penal dónde las dificultades del paso del Derecho indiano al patrio adquieren mayor relevancia. El Derecho penal indiano conocido en esta parte de América no alcanzó a recoger los planteamientos ilustrados del siglo XVIII, siendo una de las prioridades de los gobiernos nacionales la rápida creación de un Derecho penal que recoja los principios de respeto a la persona humana que campearon la doctrina penal desde el siglo citado. Se constata la falta de penas adecuadas para la reprensión de un número importante de delitos. Muy ilustrativas de esta realidad son las palabras del ministro de justicia Manuel Montt Torres en su cuenta del año 1841 señala: "Inutilmente las leyes deslindarían los derechos de los individuos y señalarían penas a los delincuentes, si una viciosa y desconcertada administración de justicia entorpecía el efecto de esas mismas leyes, complicando en tramitaciones absurdas las cuestiones que se suscitasen" 62 .

El principio fundante de todo el planteamiento es que la represión de la delincuencia no puede pugnar con los medios necesarios para la protección de la inocencia y defensa de los acusados. Tales medios de protección de la inocencia y defensa consistían en la ejecución exacta de la sentencia, no pudiendo exceder el presidio el término consignado en ella; y en la imposibilidad de ser condenado por la declaración de testigos que el imputado o el juez no hubieren oído ni examinado, teniendo Derecho el acusado a ver a los testigos y acusadores y teniendo Derecho a contra interrogarlos y pedirles razón de sus dichos; y por último el principio de la inmediación del juez, no pudiendo éste delegar en subalternos la rendición de la prueba.

En materia carcelaria los problemas fueron bastante mayores. El sistema de presidio ambulante, para los reos de mayor condena, no permitía la rehabilitación del delincuente y era extremadamente feble en materia de seguridad ${ }^{63}$.

\footnotetext{
${ }^{61}$ DL. (1842-1846), II, p. 442.

${ }^{62} D L . \mathrm{I}(1831-1841)$ p. 226

${ }^{63}$ Como dato de carácter ilustrativo la memoria del año 1841 informa que ese año en los presidios ambulantes se produjo un violento motín que fue sofocado "con escarmiento horrible que consternó a los ciudadanos y al Gobierno". p. 227
} 
Ese sistema se explicaba por la carencia de cárceles en gran parte de las ciudades o estado de ruina en que estas se encontraban. En los campos la cárcel era la casa que servía de residencia al juez. Esos establecimientos no permitían la carísima enseñanza moral y religiosa, con la cual los reos podrían arrepentirse y cambiar de vida ${ }^{64}$.

Por ello se buscó una isla que pudiese alimentar, dar trabajo y readaptar a los reos. En 1839 se pensaba en recuperar para esos fines la isla Robinson Crusoe, la que perdió ese uso con ocasión de la guerra contra la Confederación. Se la quiso destinar para los reos de mayor peligrosidad y que hubiesen cometido delitos atroces, dado que desde ahí no se podrían fugar. Dos años después, se desistió del archipiélago de Juan Fernández y en su lugar se propuso la isla Mocha, en razón de la feracidad de su suelo y suavidad de su clima.

De esa idea el gobierno también se desistió, al constatar que el estrecho que la separa del continente es corto y las mareas ayudarían a eventuales fugas.

En su lugar, en 1842, se planteó usar como presidio la parte sur de la isla grande de Chiloé, dado que ahí se podrían dedicar a la tala de árboles, el cultivo de la tierra y podrían llevar a sus familias, para que formen colonias de pobladores. Posteriormente, en 1847, se optó por mandar "aquellos reos cuyos delitos no anuncian un corazón depravado o pervertido" al Estrecho de Magallanes concediéndole Consejo de Estado algunas conmutaciones a los reos que allá fuesen remitidos.

En definitiva, ninguna de estas iniciativas prosperó o tuvo éxito ${ }^{65}$. Todas implicaban costos muy altos y, si bien siguieron latentes en el tiempo, la solución encontrada al déficit carcelario fue en otra dirección. Ya en 1843 se piensa que la única idea viable es la construcción de una cárcel en las afueras de Santiago, que siguiese el modelo de reclusión adoptada en las prisiones de los Estados Unidos de Norteamérica. Este consistía en cárceles con celdas individuales, en las que pernoctan y se alimentan, estando los detenidos separados de los reos rematados, siendo objeto de educación religiosa, instrucción primaria y del aprendizaje de algún oficio lucrativo que les garantice una posterior subsistencia honesta.

Para ese fin se concibió construir una cárcel modelo inspirada en ese arquetipo. Este recinto debía ubicarse cerca de Santiago y ser un local de presidio y readaptación. Desde el principio se lo denominó Penitenciaría y acorde a sus resultados, se extrapolaría ese modelo al resto del país. Su construcción fue un proceso rápido. $\mathrm{Al}$ año siguiente ya estaba funcionando. Su instalación implicó el cese del presidio ambulante.

En ella levantaron talleres de zapatería, carpintería, herrería y sastrería, cuyos productos se vendían a módicas sumas. Al cabo de unos pocos años, deducidos los costos de herramientas y materias primas, comenzó a dar utilidades, las que

${ }^{64}$ DL. I (1831-1841). p. 219

${ }^{65}$ Recién en 1855 se informa la reclusión de 85 reos en la isla grande del archipiélago de Juan Fernández. Se concluye que si bien esa cárcel ha recibido algunas mejoras, sigue siendo extremadamente cara. Debe ser abastecida desde Valparaíso, lo que aparte de ser costoso, es muy difícil. Las razones geográficas, a su vez, hacen muy complejo llevar un adecuado control de lo que sucede dentro de la prisión y, a la larga, debería darse un aumento de sueldo a los que allí laboran para que quieran permanecer allá. 
se distribuían entre los reos, por concepto de pago de jornales, comisiones de venta y utilidades para la penitenciaría, en proporciones de $60 \%, 23 \%$ y $17 \%$ respectivamente ${ }^{66}$. El valor de esos trabajos se fue incrementando de manera paulatina. Mientras en 1862 estos fueron tasados en \$19.171, al año siguiente estos ascendieron a $\$ 29.879$, de los cuales se obtuvo un porcentaje de utilidades que se distribuía de la forma antes indicada, guardándose el dinero correspondiente al sueldo de cada reo para entregárselo al momento de su excarcelación, a fin que tuviese un capital con el cual desempeñarse como trabajador por cuenta propia en el oficio que aprendió en la penitenciaría.

El régimen penitenciario también incluía programas de alfabetización y evangelización. Para ello se comisionó a un preceptor titulado en la escuela normal. Se buscaba que el reo, mediante la lectura, la escritura y la instrucción religiosa, tuviera conciencia de sus errores y de cuál era la moral imperante en el país. La escuela funcionaba los días festivos y los martes y viernes de cada semana, contando con doscientos diez alumnos ${ }^{67}$.

La evangelización, por su parte, en la década de 1860, fue encomendada a la Congregación de San Vicente de Paul. Ellos quedaron a cargo de la educación religiosa, administración de los sacramentos y asistencia espiritual de los reos ${ }^{68}$.

El modelo de la penitenciaría, en general, fue bien evaluado en este período por las autoridades ejecutivas, razón por la cual se pensó prontamente en reproducirlo en Talca, Valdivia y Coquimbo, a fin de evitar el traslado de los reos peligrosos a Santiago y readaptar socialmente a los presos en sus regiones ${ }^{69}$.

En materia carcelaria, también había diferencias de género. Mientras el delincuente varón iba a la cárcel, la mujer iba a la casa correccional. Las ocupaciones a las que ellas debían ser destinadas eran las propias de su sexo, enseñándoles un oficio vinculado a estas labores, que les permitiera recuperar la libertad sin tener que volver a delinquir ${ }^{70}$.

Para cumplir con ese objeto, el gobierno solicitó en Europa el envío de monjas de la Congregación del Buen Pastor, a fin que fuesen las religiosas de esa orden las que tuvieran la dirección y la tutela de esa casa de corrección, en razón de su particular carisma ${ }^{71}$.

Desgraciadamente, el debut de las religiosas en esta materia no fue fácil dado que no contaban con las instalaciones adecuadas para realizar su encargo y, para las casas correccionales no hubo la determinación política que sí se tuvo para

${ }^{66}$ Porcentajes calculados en base a los datos proporcionados en la memoria del año 1861, p. 317. De un total de $\$ 4.958$, para el pago de jornales se destinaron $\$ 3.069$, a la comisión de ventas, $\$ 1.185$ y a las utilidades de la casa, $\$ 704$.

${ }^{67}$ Memoria del ministro de Justicia, Culto e Instrucción Pública, Año 1864, p. 13.

${ }^{68}$ Memoria del ministro de Justicia, Culto e Instrucción Pública, Año 1865, p. 18

${ }^{69}$ Memoria del ministro de Justicia, Culto e Instrucción Pública, Año 1867, p. 11

${ }^{70}$ DL. (1842-1846), II, p. 264.

${ }^{71}$ Es así como la memoria del año 1864, en su página 15 dice: "Las monjas del Buen Pastor contraidas por el exclusivo objeto de su institución a la práctica constante de las medidas más eficaces para modificar los hábitos viciosos de la mujer extraviada, son sin duda las llamadas para dirigir con ventaja el establecimiento de que trato". 
prestar dineros a los municipios, destinados a la reconstrucción y mejoramiento de las cárceles. Hubo meras declaraciones de intenciones ${ }^{72}$.

Como los fines que el legislador quería para la pena se podían ver frustrados por problemas suscitados dentro del penal, o como otro medio de garantir los principios y valores en que se fundaba el Derecho y la política criminal vigente, se regularon las visitas carcelarias, estatuyendo la obligación de jueces y escribanos de efectuarla todos los sábados del mes, a fin de mantener un control del estado de avance de todas las causas ${ }^{73}$.

La administración y propiedad de las cárceles fue otro problema de este período. A excepción de la penitenciaría de Santiago, una suerte de cárcel modelo, casi todas eran propiedad de los municipios. Las municipalidades no disponían de los recursos para construir grandes presidios, que hubiese módulos individuales y lugar para talleres e instrucción religiosa. Por el contrario, muchas municipalidades poseían erarios paupérrimos y apenas podían mantener edificios que se encontraban casi en la ruina. Por ello en varias cuentas, el ejecutivo informa que en la ley de presupuestos se han destinado fondos afectos a la reparación de cárceles, vía transferencia desde el fisco al municipio. Tal fue el caso de San Fernando, Rere, Rancagua, Elqui, San Felipe y Quillota ${ }^{74}$. En 1854 tocó el turno a las ciudades de Chillán, Cauquenes, Combarbalá, Curicó y Molina. En 1855, tuvieron similar suerte las ciudades de Talca, Puchacai, Petorca y Melipilla.

Luego, en 1857, se repararon o levantaron presidios pertenecientes a Santa Rosa de los Andes, Tomé, Osorno y Achao y al año siguiente se transfirieron fondos para la reparación de las cárceles de Talcahuano, Rengo, Quirihue, Los Ángeles y Puerto Montt.

Es inherente al todo sistema carcelario que un porcentaje de la población penal se va a fugar del recinto en que cumple condena. Tal situación en el período en estudio no fue poco común, debido al mal estado de las cárceles. Este hecho generó un vicio legal: los reos conseguían su impunidad con el mero cambio de domicilio. Los jueces competentes en sus nuevos domicilios carecían de los antecedentes o del prontuario del nuevo vecino, por lo que, a partir de 1860, se comenzó a confeccionar una lista detallada de los reos fugados de cada una de las cárceles, para de este modo facilitar su detención ${ }^{75}$.

Curiosamente, siendo siempre el principal motivo de la pena el escarmiento y la protección de la sociedad frente a los que buscan romper las reglas que ésta ha impuesto, el fin preventivo no es desarrollado a lo largo de estos documentos. Se da por supuesto. Lo que interesa es la conversión y moralización del delincuente, como se desprende de las discusiones citadas.

También dentro de la esfera penal se encontraba la regulación de la libertad de imprenta. Si bien no se desconocían los enormes beneficios educativos de la prensa, y sus beneficios para la civilización de los pueblos, el ejecutivo, el año 1846 decidió que la protección del orden y la honra de las personas debían quedar

\footnotetext{
${ }^{72}$ Memoria del ministro de Justicia, Culto e Instrucción Pública, Año 1867, p. 11

${ }^{73}$ DL. (1847-1851), III, p. 446.

${ }^{74} \mathrm{DL} .(1847-1851)$, III, p. 676.

${ }^{75}$ DL. (1860), VIII, p. 73.
} 
dentro del ámbito penal. Curiosamente, no se concibe la protección de la honra mediante un adecuado sistema de responsabilidad civil extracontractual.

La idea subyacente es el control del orden público. El enfoque dado a la imprenta está centrado en la defensa de los valores vigentes en ese momento y en el temor a eventuales alteraciones del orden público. Mediante la imprenta se podía incentivar el desorden y la inmoralidad pública ${ }^{76}$.

\section{EL ROL DE LOS ABOGADOS}

En la primera etapa, una de las preocupaciones fue el fortalecimiento de los estudios jurídicos en Chile, la disponibilidad de una buena biblioteca en Santiago y la excelencia y probidad de los abogados y de quienes ejercían los cargos auxiliares en la administración de justicia.

En tal sentido, el Estado asumió el rol de garante de la calidad de estos servicios, constituyéndose por ley en el único autorizado para proveer los puestos de escribano, procurador y receptor, a los que se eleva a la categoría de cargos públicos. De esta forma se entendió que se daba importancia a los oficios que cada uno de ellos despeñaba, se aseguraba que el servicio proveído fuese el óptimo y se obligaba a los adjudicatarios de tales oficios a rendir una fianza, cuyo monto era determinado en razón del número de habitantes del distrito en que eran competentes y el número de responsabilidades que recaían sobre sus hombros ${ }^{77}$.

La primera rendición de cuentas del ministro Manuel Montt volvió a tratar este tema, desde la óptica de la necesidad de aumentar la ilustración y los conocimientos de los abogados, para que, en su calidad de coadyuvantes en la administración de justicia, pudiesen constituirse en una opinión autorizara que participara en el debate sobre mejores y reformas en el poder judicial, los nuevos procedimientos, las lagunas legales y su integración. Por esa razón es que planteó la enorme utilidad y la satisfacción con la que el gobierno vería la formación de un colegio de abogados ${ }^{78}$.

Dicho organismo corporativo, a ojos de los documentos estudiados, permitiría aumentar los lazos de fraternidad, tan necesarios en el foro, y potenciaría los conocimientos de los juristas.

Asimismo, el año 1842, el gobierno informa al congreso sobre las medidas tendentes a que aquellos que ejercen en el foro tengan los conocimientos y calidades adecuados para tan delicada labor ${ }^{79}$. En tal sentido, se dictó un decreto para

${ }^{76}$ DL. (1842-1846), II, p. 438

${ }^{77}$ DL. (1831-1841), I, p. 206.

${ }^{78}$ Sobre este punto es necesario recalcar que esta propuesta sólo viene a poner en tabla una faceta extremadamente postergada en el desarrollo de la profesión jurídica en Chile. Desde el momento en que se planteó esta idea al efecto de su concreción, mediaron casi dos décadas, fundándose el primer colegio de abogados recién en 1862, corporación que tuvo una corta vida de escasos cuatro años. Si se compara al colegio de abogados de Chile, con el Real Colegio de Abogados de México, fundado en 1760 y el de Lima, que data del año 1804, se comprende cuán atrasado estaba el medio jurídico chileno en este punto.

${ }^{79} \mathrm{El}$ aseguramiento de la calidad profesional de los abogados y los grados necesarios para el ejercicio profesional constituyeron un solo tema que en el Derecho patrio se instaló tan 
que los bachilleres que postulasen a la academia de leyes forenses, presentasen a la Corte de Apelaciones, además del certificado de graduación de la Universidad, otro que informase que sus estudios se hicieron de acuerdo a las leyes vigentes ${ }^{80}$. Comienza a instalarse la preocupación porque los abogados no sólo manejen la doctrina $^{81}$. y los lineamientos del sistema del Derecho común, sino que ante los tribunales aleguen en base al nuevo Derecho, al Derecho patrio surgido desde el momento de la emancipación. Es una necesidad patente que el Derecho nacional comience a tener independencia científica y sea objeto de estudio. Por ende, requería que los operadores jurídicos manejasen el nuevo Derecho. Se avanza en un proceso de nacionalización jurídica.

La nacionalización jurídica implicaba dar una sistematización al Derecho patrio entendiendo que era parte de una familia jurídica. Por eso, las reformas de planes y programas y las nuevas exigencias para el ejercicio profesional no eran suficientes. Fue necesario adquirir en Europa una biblioteca de Derecho que contuviera las principales obras de jurisprudencia que hubiese encargado el Gobierno de Francia. Esta se ubicó en dependencias de la Corte Suprema.

Paralelamente, se adoptó igual medida con ocasión de la erección de las cortes de apelaciones de La Serena y Concepción, siendo ambos tribunales dotados de bibliotecas que estaban a disposición del medio jurídico local. A partir de 1860, se busca dotar a todos los tribunales de bibliotecas que reúnan las principales obras de Derecho necesarias para un acertado desempeño en tribunales. Ante la

luego como destellaron los primeros albores de la vida republicana. El año citado el objetivo era cautelar el ejercicio y los conocimientos de aquellos que se habían formado antes de la fundación de la Universidad de Chile. Desde 1810 hasta la fundación de la Universidad de Chile, su antecesora, la Universidad de San Felipe, se limitó a actuar como academia, siendo privada de sus funciones docentes que tanta relevancia le dieron en la época indiana. La enseñanza del Derecho, por ende, estuvo a cargo del Instituto Nacional y de colegios privados de corta vida y distinta calidad, como fueron el Liceo de Chile, el Colegio de Santiago, el colegio del diplomático francés Juan Zegers, el regentado por el presbítero Juan de Dios Romo, el Colegio de los hermanos Zapata y el liceo Casa de Educación. La emancipación, como señala el profesor Alejandro Guzmán Brito, rompió el sistema de titulación legado por el Derecho indiano, consistente en la sucesión de los grados de bachiller, licenciado y doctor, junto al título de abogado, ideado sobre la base de la progresiva adquisición de los conocimientos y las competencias requeridas para el ejercicio profesional. El mundo indiano suponía que no era lo mismo la formación académica, centrada en aquella época en el sistema del Derecho común, y la preparación en la praxis profesional, con las leyes vigentes y regularmente citadas en el foro, para cuya instrucción estaba la Academia de Leyes Reales y Prácticas Forenses. Tal diferenciación de aspectos formativos no quedó del todo clara en el período de la memoria aludida, ya que si bien la enseñanza práctica siguió a cargo de la Academia, ahora con el nombre de Academia de Leyes y Práctica Forense, la enseñanza de corte teórico quedó a cargo de instituciones en que se daba prioridad a la doctrina y a los grandes sistemas jurídicos y no a la legislación vigente. Sobre el tema de los grados y la enseñanza del Derecho en Chile, véase: Guzmán Brito, Alejandro, La enseñanza del Derecho. Historia y perspectivas, en Anales del Instituto de Chile, 25: Estudios II: La educación superior en Chile (Santiago, 2005-2006), pp. 273 ss.

${ }^{80}$ DL. (1842-1846), II, p. 26

${ }^{81}$ A modo de ejemplo, véase: DE MORA, José Joaquín, Curso de Derecho en el Liceo de Chile: Derecho natural y Derecho de Jentes. (Santiago, Imprenta Republicana, 1830). 
existencia de una sola escuela de Derecho, en Santiago, se pretende que sean los tribunales los que irradien los avances de las ciencias jurídicas en el foro nacional. El tribunal no sólo es foro sino biblioteca ${ }^{82}$.

También esa memoria da cuenta de otro decreto que autoriza a nacionales de otros países que conserven la legislación hispana, para que puedan ejercer libremente la profesión en Chile: "Se ha tratado de dejar libre entrada a las personas inteligentes que pretendan ejercer esta honrosa profesión entre nosotros" 83.

Si bien esta apertura a abogados de otras latitudes continuó, el progresivo paso de un Derecho de juristas a uno de corte legal, y la rápida nacionalización del Derecho, con la correlativa perdida de vigencia de normas que antes eran aplicables en todo el continente, llevó a cambiar los requisitos para autorizar el ejercicio de la abogacía en Chile. Para tal efecto, los grados conferidos por universidades extranjeras, reconocidas por Chile, debían presentar certificado de aprobación de exámenes de códigos chilenos y práctica forense, para que sus diplomas sean validados por la Facultad de Derecho de la Universidad de Chile ${ }^{84}$.

El año 1854 se informa de importantes cambios en la malla curricular de la Facultad de Derecho de la Universidad de Chile, enfocada a extender los estudios a disciplinas hasta ese momento desconocidas en el aula, como el Derecho administrativo y el Derecho comercial ${ }^{85}$. Tres años después, con ocasión de la entrada en vigencia del Código Civil, se sustituye en la referida facultad el estudio del Derecho español por el Derecho civil, atendido a que en los años siguientes el Derecho hispano perdería gran parte de su vigencia en la nueva república.

Asimismo se incorpora al plan de estudios el Derecho minero y se da mayor extensión al estudio del Derecho romano y de la economía política.

Cambió también el método de enseñanza, al pasar desde los compendios y obras de los grandes jurisconsultos con los que se guiaban los tribunales, al estudio de la letra de la ley ${ }^{86}$.

El año 1860 se da cuenta de la pronta elaboración de una ley que regule el rol, responsabilidades, requisitos y aranceles que cobran los notarios. Al ser ellos los únicos depositarios de conocimientos legales en los pueblos, su rol debe ser muy bien regulado. En ellos recaía mucho más que la fe pública. Eran los guardianes del Derecho en muchos lugares en que no había abogados.

$\mathrm{Al}$ año siguiente, en el mismo sentido de mejorar la formación de los abogados y demás operadores jurídicos, y darles más destreza en el foro, se inicia la redacción de un prontuario de leyes y decretos vigentes, con las explicaciones correspondientes sobre su sentido y alcance. Este prontuario se distribuyó, preferentemente, entre los jueces de primera instancia inferiores.

Con ese mismo fin educativo, en 1857, se comenzó a dar forma a la Gaceta de los Tribunales, publicación de carácter periódico que obligada a los jueces letrados del país a entregar mensualmente al ministerio de justicia copias autorizadas de

\footnotetext{
${ }^{82}$ DL. (1861), IX, p. 315.

${ }^{83}$ Ibíd.

${ }^{84}$ Memoria del ministro de Justicia, Culto e Instrucción Pública, Año 1864, p. 28

${ }^{85}$ DL. (1854-1856), V, pp. 103-104

${ }^{86} D L$. (1860), VIII, pp. 82-83
} 
todas las sentencias firmes o ejecutoriadas, a fin que se inserten con posterioridad en esa revista ${ }^{87}$.

En materia de defensa ante los tribunales, el ministerio da cuenta que por Ley del 18 de mayo de 1839, se aumentó el número de abogados y procuradores destinados a la defensa de los menesterosos, estableciendo un registro público de providencias judiciales que prohibían la enajenación de los bienes indispensables para llevar una vida digna, que con ocasión de un juicio el necesitado se veía en la obligación de vender.

Tal política de defensa gratuita para los pobres se extendió durante los años siguientes. Así en 1847 se informa que los intendentes de Concepción y Atacama entregaron al gobierno datos acerca de la conveniencia de contar en sus capitales con procuradores destinados a ese fin.

\section{CODIFICACIÓN}

El proceso codificador en este período está en sus albores. Constituye la esperanza que nunca se pierde. Siempre se da cuenta de su necesidad, mas la poca gente preparada para redactar los códigos, unido a necesidades urgentes que permanentemente distraían a los diputados para tales tareas, lo constituyen un espejismo, que se repite año a año, cuál promesa que al siguiente si se podrán presentar los proyectos ante el congreso.

Como decíamos más arriba, en algunas materias, los sueños y elucubraciones acerca de la cuál debe elaborarse primero v. gr. el código orgánico, el de procedimiento civil o el de procedimiento penal, constituyeron nada más que discusiones anodinas, superadas por la necesidad de dar respuesta a los problemas inmediatos. Fue la sabia idea de fortalecer las instituciones y respetar los principios generales del Derecho la que permitió la dictación de normas de pequeño alcance que reformaron paulatinamente la legislación heredada las que permitieron allanar el camino a códigos de larga vigencia.

Fue la evolución jurídica y el respeto a las normas y el estado Derecho los que pavimentaron el camino para códigos que, en su mayoría, son muy posteriores a la época en estudio.

Ya en la memoria de 1847 existe la certeza que el primero de los códigos será el de Derecho civil; sin embargo, le queda aún un tiempo para su revisión y eventual enmienda. En ese mismo documento, se manifiesta la necesidad que, después del código civil, vengan los códigos referidos al Derecho procesal.

También en este período se incuba la necesidad de redactar un código de minería. Esa actividad era fundamental para el desarrollo económico nacional y había tenido un crecimiento explosivo desde la década de 1830 . Se requería urgente una reforma que colocase a la legislación en armonía con los progresos de la técnica. La legislación indiana no contemplaba la explotación de combustibles fósiles ni tampoco incorporaba los conocimientos de la ingeniería en minas, que

${ }^{87}$ DL. (1857-1858), VI, p. 311 
daba nuevas herramientas para garantizar el efectivo respeto de los derechos de los particulares sobre las concesiones y exploraciones.

El Derecho minero también adolecía del vicio de la confusión de funciones. Los funcionarios públicos también eran jueces especiales en esta materia: "Las funciones de los diputados de minas son inconciliables con la posición de un Intendente o Gobernador como agentes del Ejecutivo"s8.

También consagró los desvelos del ministerio, a contar de la década de 1860, la reforma al código militar, dado que esta permitía que las sentencias emanadas de los tribunales especiales de justicia militar no cumplieran con los requisitos básicos de contar con una relación ajustada de los hechos ni señalar los fundamentos legales de la decisión adoptada, dictando penas draconianas que debían ser conmutadas por el presidente de la república, en virtud del artículo $82 \mathrm{~N}^{\circ} 15 \mathrm{de}$ la Constitución. Muchos de los condenados por delitos militares, como deserción y abandono de guardia, de no aplicarse esa facultad del presidente, terminaban presos en la penitenciaría de Santiago, ocupando una celda que estaba originalmente destinada a reos condenados por delitos graves y de alta connotación social. Las normas vigentes en ese momento en materia de justicia militar impedían la correcta destinación de los recursos contemplados por el Estado para la política criminal de reinserción del delincuente. Tal situación justificaba la conmutación de las penas por otras menos rigurosas como la relegación ${ }^{89}$.

Como última mención de relevancia del período examinado, es oportuno destacar la discusión suscitada con ocasión de la regulación del negocio farmacéutico. Cada químico preparaba los medicamentos con la formula que el estimaba conveniente, en las proporciones que cada cual prefería, por lo que los médicos ignoraban la calidad y composición química de las medicinas. No había certeza alguna para los galenos en cuanto a recetas ni de dosis necesarios para un buen tratamiento.

Tal situación no pasó inadvertida para la sociedad de farmacia ni para la Facultad de Medicina de la Universidad de Chile, las que oportuna y reiteradamente hicieron ver el peligro de esa situación. Algunos se regían por la farmacopea de Londres, otros por la de Hamburgo, otros por la francesa y un último grupo se regía por las prescripciones de Parma.

La única solución que se concibió para estos efectos fue la dictación de una ordenanza general. El Estado actuó como regulador y garante del bien común. Entra a regular el ejercicio de los farmacéuticos, a fin de evitar una anarquía basada en el laissez faire, con inminentes y graves consecuencias ${ }^{90}$.

\section{SitUACIÓN DEL INDÍGENA}

Dentro de las preocupaciones manifestadas en la década de 1840 por los ministros de justicia está el tema del indígena y el conjunto de normas que se deben aplicar en las relaciones de estos con el resto de los chilenos.

\footnotetext{
${ }^{88}$ DL. (1861), IX, p. 310

${ }^{89}$ Memoria del Ministro de Justicia, Culto e Instrucción Pública, Año 1865, p. 15.

${ }^{90}$ Memoria del Ministro de justicia, Culto e Instrucción Pública, Año 1873, p. 10 ss.
} 
El ministro de Justicia, Culto e Instrucción Pública Salvador Sanfuentes, preocupado de prevenir futuros semilleros de conflictos, ya en 1848 manifiesta su preocupación por la ausencia de una legislación clara y pormenorizada sobre la compraventa de tierras entre indígenas y chilenos. Le inquieta la eventual falta de garantía a los compradores y la acumulación de vastas extensiones de tierra en muy pocas manos.

Años después, en 1864, se informa de la suspensión de los notarios de Nacimiento y Arauco, por otorgar instrumentos de enajenación de terrenos indígenas sin cumplir con las disposiciones establecidas en decretos supremos para regular los contratos de compraventa entre chilenos y mapuches. El ministro estimó que dichos instrumentos eran fraudulentos; sin embargo no hubo medida que declarara la nulidad de estos, por estimar que incurrieron en un mero error ${ }^{91}$.

En las memorias posteriores del período en análisis, no hay mención jurídica a esta problemática, pese a ser en esos años aquellos en que adquiere mayor rapidez la denominada pacificación de la Araucanía.

\section{Libertad de Culto}

Este tema se desarrolla por primera vez en la memoria del año 1849, de manera breve y sucinta, con miras a la implementación de políticas migratorias que traigan al país personas que puedan ser un aporte al desarrollo del país.

En ese contexto se reconoce que en los hechos existe en el país la tolerancia religiosa; no obstante, la disposición constitucional que reconoce la confesionalidad del Estado.

La postura del ejecutivo frente a este Derecho carente de consagración legal o constitucional es mantener la situación existente; es decir, tolerancia religiosa o libertad de cultos en los hechos pero no en el Derecho.

Se fundamenta esa postura en la necesidad de conservar por el mayor tiempo posible una de las ventajas heredadas de la dominación hispana: la unidad religiosa; del mismo modo en que lo tuvo en cuenta la convención que redactó la carta fundamental de 1833.

Hay temor a que el reconocimiento legal de la libertad de cultos lleve a la pérdida de la unidad religiosa y, a la larga, esto sólo sea sinónimo de conflictos y cruentas guerras como las que padeció Europa después de la reforma religiosa del siglo XVI. Prácticamente, se repiten de forma abreviada los mismos argumentos entregados por Juan Egaña Risco un cuarto de siglo antes, en su tratado Memoria Política sobre si conviene a Chile la Libertad de Cultos ${ }^{92}$.

La conveniencia de mantener esta libertad en los hechos posibilitará, en opinión del ejecutivo, la llegada de extranjeros de calidad, que no profesan el credo católico, rompiendo de esta forma el aislamiento tan característico de Chile. Ellos entregarían su conocimiento y hábitos de trabajo mejorando la calidad de vida de los chilenos. Ante tantos beneficios que se recibirían, lo mínimo que se les

\footnotetext{
${ }^{91}$ Memoria del Ministro de Justicia, Culto e Instrucción Pública, Año 1864, p. 9

${ }^{92}$ Obra disponible en: www.memoriachilena.cl
} 
podía ofrecer era continuar profesando su credo religioso, modificando también las leyes matrimoniales, a fin que la diferencia de cultos no sea impedimento para contraer matrimonio ${ }^{93}$.

Este tema volvió a abordarse el año 1865, con ocasión de la ley interpretativa del artículo $5^{\circ}$ de la Constitución, que establecía la confesionalidad del Estado. Esa memoria, reprodujo una vez más lo planteado en su oportunidad por el jurisconsulto Juan Egaña, recalcando la diferencia entre el ejercicio público y el privado de la religión, fundándose para ello en el inalienable Derecho a la libertad de conciencia y de pensamiento. La práctica de cultos disidentes dentro de un recinto privado no puede entenderse, entonces, como una práctica que transgrede el ordenamiento jurídico patrio. Lo que se prohíbe es el culto público y la propaganda disidente. Se quiere proteger a toda costa la unidad religiosa del país.

Tal interés sin embargo no puede atentar contra al libertad de enseñanza y el derecho de los padres a dar instrucción religiosa a sus hijos, por lo que el artículo 2 de la ley interpretativa mencionada reconoce el derecho de los disidentes a sostener escuelas privadas para instruir a sus hijos en la doctrina de su credo.

Sobre este último artículo, el raciocinio jurídico del ejecutivo es que no debe entenderse que posee un carácter interpretativo de la Constitución, toda vez que este Derecho jamás ha estado en discusión, y la Constitución y la práctica jurídica y social del país siempre lo han reconocido. Sólo se incorporó como una nueva garantía de carácter legal.

Tal norma prosigue con el carácter utilitario dado a la inmigración en este período. Se busca favorecer una inmigración selectiva de extranjeros útiles al país, a los que se les quiere dar en los hechos buenas condiciones, lo que incluye la libertad de culto y la tolerancia religiosa, entendidos como la posibilidad de profesar su fe, instruir a sus hijos; pero no alterar la unidad religiosa del país. Subyace el temor al extranjero que no tenga cualidades escasas en este suelo ${ }^{94}$.

\section{Xi. Patronato}

A diferencia de otros de los puntos analizados, en materia de relación entre la Iglesia y el Estado, no hay reformas pendientes desde la época indiana ni la necesidad de cambiar la sistematización de la normativa vigente. No hay necesidad de códigos eclesiásticos.

Por ende, en este punto el esfuerzo legislativo y gubernamental irá en dos sentidos: recomponer las relaciones con la Santa Sede, con miras a obtener de esta el reconocimiento de Chile como país independiente, y la nacionalización del Derecho eclesiástico. La Iglesia está unida al Estado y si cambia uno, necesariamente debe cambiar el otro. Ha nacido un nuevo Estado y se requiere que la Iglesia sea funcional a los fines de ese Estado.

Lo anterior no quiere decir que el proceso emancipador haya implicado un quiebre en aspectos teológicos o morales. Hay un área de la vida social y jurídica

\footnotetext{
${ }^{93}$ DL. (1847-1851), III, p. 292.

${ }^{94}$ Memoria del Ministro de Justicia, Culto e Instrucción Pública, Año 1865, pp. 21 ss.
} 
que será de competencia exclusiva de la Iglesia hasta la década de 1880. Moral y religión son entendidas como sinónimos y se comprende que en materia educativa Iglesia y Estado son pilares coadyuvantes.

En consecuencia, del real patronato al patronato estatal consagrado en la Constitución no hubo cambios sustantivos.

Los cambios buscan adaptar la estructura imperial a la organización de la naciente república. La República de Chile sigue siendo eminentemente regalista, financia a la Iglesia y se sirve de ella. Nadie discute que Chile es una república católica, ni se cuestiona que la confesionalidad estatal tenga rango constitucional.

Tampoco hay un cuestionamiento conducente a fortalecer la autonomía de la Iglesia frente al poder temporal. Las primeras voces nacionales tendentes a lograr un mayor grado de autonomía recién se escucharán en la década de 1850 .

El regalismo es parte de la mentalidad de la época y su sustitución por ideas ultramontanas será un proceso lento que demandará varias décadas.

Durante éste período sigue siendo muy importante que la población tenga acceso a los sacramentos y que los feligreses hagan penitencia ${ }^{95}$.

El actuar del gobierno sólo se hace eco de esas ideas. Como en otros temas ya estudiados, una vez más el ministro de justicia Mariano Egaña resumirá en pocas palabras lo que será la política estatal en este aspecto, y cuáles serán los principios rectores del caso: "El gobierno ha atendido todo lo perteneciente al culto, proveyendo a las urgentes necesidades de la Iglesia chilena. Ha llevado a efecto la ley que mandó a proveer la erección de una metrópoli eclesiástica y de otras dos sillas episcopales, y a presentado los prelados para gobernarlas. La de consultar en esta erección la incolumnidad y conservación de los derechos del patronato, mantener el dominio nacional de los diezmos, y cuidar de que la erección se verificase por las personas señaladas por el gobierno $[. . .]^{" 96}$.

Todo lo anterior queda de manifiesto en que las reformas a las comunidades religiosas las impulsa el gobierno, que es por medio de una ley que se regula la dependencia y el domicilio de los religiosos extranjeros y se refuerzan las disposiciones que autorizan el exequatur. En virtud de la disciplina eclesiástica y los efectos de su relajación en la moral pública y en la educación de la población, el Estado regula aspectos propios del Derecho canónico. Tan severo es este celo que una ley patria restableció la ley $38^{\mathrm{a}}$, del libro VI, título $1^{\circ}$ de la Recopilación de Leyes de Indias, que entregaba el cuidado de la conducta de los párrocos no as u superior jerárquico sino al patrono. En este caso al Estado, representado por el Presidente de la República: "Nada hay más funesto para la moral pública que los ejemplos de depravación de los párrocos." 97.

Los sucesivos gobiernos eran conscientes que los mayores problemas sociales se daban en los campos, donde vivía gran parte de la población y esta carece de una

${ }^{95}$ Esta idea dieciochesca se precia con particular fuerza en la memoria del año 1843 , en que es motivo de loa y reconocimiento la visita que en su diócesis ha hecho el Obispo de Concepción, encargándose personalmente de velar por una mejor administración del culto y por acercar los sacramentos a las personas.

${ }^{96}$ DL. (1831-1841), I, p. 208

${ }^{97}$ Ibíd. 
adecuada formación moral y religiosa, que impedía la reforma de las costumbres y entorpecía el progreso del país. El remedio para tal problema es la educación a cargo de sacerdotes. Son ellos los encargados de moralizar al campesinado. Se requieren más y mejores sacerdotes. Se necesita que el sacerdote esté disponible para ese pueblo y por ello el gobierno impulsa la división de las parroquias y el establecimiento de escuelas junto a los templos ${ }^{98}$.

Tal medida agudizó el problema de mantención de los sacerdotes. La división de algunos curatos ocasionó en varios de ellos una mengua considerable de sus ingresos, por lo que rápidamente empezó a plantearse la necesidad de una nueva política de administración y asignación de los ingresos de las diferentes parroquias a nivel nacional.

Este permanente problema posteriormente se trató de solucionar con la creación de viceparroquias.

Por otro lado, la necesidad de mantener el patronato y la independencia de Chile, llevaron a pensar de otra manera la organización administrativa de la Iglesia. Se buscaba que la organización de la Iglesia correspondiese a la organización del nuevo Estado. No era aceptable que habiendo desparecido el imperio hispano la Iglesia mantuviese una organización propia de esa época. En un momento en que se quiere fortalecer el sentimiento nacional, no es plausible que una institución tan importante tenga a sus cabezas, vale decir, a los obispos, reconociendo como obispo superior, al de Lima. Por eso se eleva por ley al Obispado de Santiago a la calidad de metropolitano. Deja de ser sufragáneo del obispado Lima. También se fundan los obispados de Coquimbo y Chiloé. Tales modificaciones legales posteriormente fueron sancionadas mediante bulas papales, "en que se accedió a las preces dirigidas por el gobierno y la legislatura" 9 .

Tal respetuoso fue el gobierno del poder papal que, recibida la sanción pontificia de los nuevos obispados, estos no recibieron pronta implementación administrativa por haber fallecido la persona designada para uno de ellos y no haber presentado aún a la persona que debía ocupar ese sillón. El Gobierno defendió con energía las potestades heredadas del imperio hispánico. Se mantienen las potestades de la corona en una nueva república.

$\mathrm{Al}$ año siguiente, la memoria respectiva da cuenta del pase a la bula que autorizó la erección del obispado de Coquimbo, exponiendo al congreso que el gobierno hizo una defensa adecuada de las regalías del patronato nacional y que se implementó el cabildo eclesiástico de la catedral de la Serena, conforme lo disponía esa bula, a pesar que la ley que dispuso la creación de esa silla no contemplaba plazo para fundar el aludido cuerpo colegiado.

Sin embargo, los conflictos suscitados con la creación del obispado de Coquimbo no quedaron ahí. La memoria del año 1842 reconoce un nuevo conflicto con la Santa Sede con ocasión de la presentación del Obispo. Es así como no fue del gusto del Consejo de Estado la bula pontificia que instituyó al obispo,

\footnotetext{
${ }^{98}$ Ibíd., p. 220
}

${ }^{99}$ Ibíd., p. 228. 
al estimar que no reconocía adecuadamente los derechos del Estado en materia de patronato.

No obstante, se concedió el exequátur a fin de evitar la vacancia del obispado y que el romano pontífice designó a la persona propuesta por el gobierno. Se optó por el bienestar espiritual del país en lugar de defender los derechos constitucionales del Presidente de la República y el Consejo de Estado.

Otra dificultad permanente, relacionada con el mismo fin, es el financiamiento del culto. Los diezmos y aranceles por la administración de los sacramentos ingresan a la Tesorería Nacional, la que destinaba los fondos ingresados conforme a las distintas necesidades del servicio religioso. El problema se daba porque los ingresos percibidos no alcanzaban para cumplir con los fines arriba propuestos y ni para dar la congrua a los religiosos y sacerdotes. Por esa razón se separó la administración de los ingresos de cada parroquia de los fondos afectos a la mantención de los sacerdotes, quedando estos últimos en manos de ecónomos particulares, los que debían dar cuenta anual al patrono; es decir, al gobierno de Chile. La fundamentación de esta medida se da por la real cédula que cayó en el desuso ${ }^{100}$, de 17 de julio de 1797 , de la ley $22^{\text {a }}$ del título $2^{\circ}$ del libro I de la Recopilación de Leyes de Indias ${ }^{101}$

Desgraciadamente, ninguna de estas propuestas parece haber funcionado, pues en 1843 ya se piensa afectar los fondos provenientes de los censos de indios a la mantención de los párrocos. También se constata que la parte de este problema se debe a la inexistencia de un arancel nacional de derechos de entierro y matrimonio, lo que lleva a que algunos sacerdotes abusen, cobrando derechos muy elevados y en otras partes los feligreses se nieguen a pagar un Derecho cobrado de manera justa. En consecuencia se buscó delimitar mediante decretos a quienes se consideraba gañanes ${ }^{102}$ y pobres, pero se esperaba la dictación de una ley ${ }^{103}$.

Imbuidos por los ideales de la codificación, los ministros de justicia pretendían que esta ley de aranceles solucionara para siempre este embarazo. Por esa razón se encargó a la Facultad de Teología de la Universidad de Chile un proyecto sobre dotación de sacerdotes. Tal trabajo demandó su tiempo y -al igual que lo sucedido en otras áreas ya mencionadas- hubo que optar por la solución concreta. La resolución de los conflictos entre párrocos y feligreses no podía seguir esperando, por lo que se acordó con el Obispo de Santiago una renovación provisional, por un período de dos años, de la autorización dada por el congreso al presidente de la república para reformar, previo acuerdo con la autoridad eclesiástica, los aranceles parroquiales, adaptándolos a las nuevas costumbres y cambios de la sociedad chilena.

Tal reforma contempló la impresión de esos aranceles y la autorización de ellas y sus copias por algunos sacerdotes, a fin de erradicar el vicio de publicar los aran-

\footnotetext{
${ }^{100}$ Ibíd.

${ }^{101}$ DL. (1842-1846), II, p. 31

${ }^{102}$ Expresión popular en Chile Central, referida al trabajador del campo.

${ }^{103}$ DL. (1842-1846), II, p. 148
} 
celes en avisos manuscritos, que se prestaban para que algunos sacerdotes elevasen el costo de estos, generando de paso la desconfianza de los peticionarios ${ }^{104}$.

En el mismo orden de ideas, otra de las preocupaciones constantes de los gobiernos de la época es la correcta administración del diezmo. No todas las parroquias pueden mantener a sus sacerdotes. De hecho se menciona que las de Ancud, Osorno y La Unión no podían hacerlo. Se propone buscar una distribución del total de lo recaudado por ese concepto conforme a los principios de la antigua legislación ${ }^{105}$.

Sin embargo, el lugar dónde mayores dificultades enfrentaban los sacerdotes en materia económica era en Chiloé. La escasez de moneda y la pobreza de la región hacían que los derechos por la administración de los sacramentos, los entierros y la limosna de la comunidad de esas islas se pagase siempre en especies y bienes consumibles, las que no podían realizarse sino con muchas dificultades y el evidente deterioro.

Tal situación fue muy palmaria después de la institución del obispado de las islas, recibiendo los sacerdotes como única renta en dinero una asignación fiscal por el título de capellanes. Por ello se propuso para ese obispado un sueldo mensual para párrocos y vicepárrocos de $\$ 500$ y $\$ 300$ respectivamente ${ }^{106}$.

Desgraciadamente, el problema de los aranceles y la administración de los sacramentos no se solucionó, por lo que en 1854 se presenta un nuevo proyecto de ley que contemplaba una exención general del pago de aranceles a los menesterosos. Para ello se insiste en la mejor y más eficiente distribución de los ingresos obtenidos por la Iglesia. En el fondo, se quiere evitar la murmuración y el desprestigio de la Iglesia y sus párrocos, pues pierden de esta forma el prestigio necesario para ser agentes moralizadores ${ }^{107}$.

Ninguna de estas ideas logró enmendar la situación de pobreza en que vivían muchos sacerdotes. La percepción por parte del gobierno sobre el fracaso de esta iniciativa fue de tal envergadura que el año 1865 se hace una nueva evaluación del problema de los aranceles, que pasa a denominar derechos de estola o aranceles compulsivos, y la legislación de dotación estatal vigente. Se vuelve una vez más al mismo diagnóstico sobre los problemas de legitimidad que traen al clero esos cobros, con la consiguiente pérdida de influencia en materias morales y de reforma de las costumbres.

Por eso el año 1864 se presentó un nuevo proyecto sobre aranceles, que consagraba una exención de estos, para aquellos que no estuvieran comprendidos dentro de las categorías de arrendatarios o dueños de inmuebles rústicos o urbanos que pagasen contribuciones, los que tuvieran establecimientos gravados con patentes, los que ejercieran profesiones liberales o científicas, los empleados públicos y los municipales, los dependientes del comercio, aquellos que actuaban como mayordomos a sueldo y los dueños de talleres o establecimientos en que trabajaban personas ajenas a sus familias.

\footnotetext{
${ }^{104} D L .(1847-1851)$, III, p. 290.

${ }^{105} D L .(1831-1841)$, I, p. 221

${ }^{106} D L .(1842-1847)$, II, p. 385

${ }^{107}$ DL. (1854-1856), V, p. 97
} 
Este proyecto establecía la obligación del Estado de cancelar mensualmente los aranceles correspondientes a aquellos que se encontraban exentos, no pudiendo esa subvención ser mayor a cincuenta centavos por óleo, dos pesos por matrimonio, un peso por entierro de párvulo y tres por entierro de adulto.

Para evitar los fraudes tan propios de este tipo de sistemas, se instituía un nuevo funcionario en cada parroquia: un ministro de fe, encargado de registrar las personas avecindadas en la parroquia, acreedoras de ese Derecho, y encargado de darles una boleta o documento habilitante de exención de pago.

Este proyecto fue rechazado por la cámara de diputados e indicado por la comisión eclesiástica del Senado.

En consecuencia se presentó otro, que establecía una subvención fiscal por cada habitante, de un monto de veinte centavos anuales, pagándose en cada parroquia de acuerdo a los datos proporcionados en cada censo. Ese proyecto no fue del agrado del ejecutivo, que no quiso apoyar su tramitación.

En consecuencia, una vez más se volvió a la vieja idea del sueldo de cargo fiscal del párroco, lo que chocaba con las muchas necesidades que debía afrontar el erario nacional y los menguados recursos que recibía ${ }^{108}$.

Por eso, en el año 1858, se opta por una solución distinta. Simplemente los ministros de culto de aquellas comunidades que no pueden pagar los aranceles parroquiales o que por sus carencias no les es posible mantener a sus sacerdotes, son declarados incongruos y se establece un sínodo ${ }^{109}$ en su beneficio.

En este mismo sentido, fue motivo de preocupación para el gobierno el elevado precio que en algunas parroquias se exigía para las dispensas matrimoniales, situación que favorecía las uniones de hecho o impedían que el matrimonio se celebrase hasta que se hubiesen reunido los recursos necesarios. Escandaliza al Gobierno de Montt la sola idea que la unión de un hombre y una mujer se hiciese fuera de la iglesia. Se argumenta que tales cobros debían bajar en razón del esfuerzo pecuniario que hacía el Estado por pagar los sínodos de los sacerdotes declarados incongruos. No se puede obstaculizar la celebración del matrimonio ${ }^{110}$.

En materia de administración económica y financiera, otro de los desvelos del gobierno la adecuada protección de la filantropía realizada a través de la Iglesia, sus congregaciones y las cofradías, denunciando que en estas últimas se solían burlas los principios y fines con que eran creadas o recibían erogaciones. Se impulsa una reforma de las normas de contabilidad de todas ellas, siendo una de las primeras cambiar su contabilidad la Congregación de San Agustín ${ }^{111}$.

Para el ejecutivo esta preocupación por la disciplina del clero también tenía un sentido utilitario. Estaba entregada a la iglesia la evangelización de los mapuches, mediante misiones de infieles. No se podía tolerar que los misioneros fuesen malos

${ }^{108}$ Memoria del Ministro de Justicia, Culto e Instrucción Pública, Año 1865, pp. 25 ss.

${ }^{109}$ Esta expresión es empleada en los documentos estudiados en su sentido distinto de aquel que le da el Diccionario de la Real Academia Española. Las memorias se refieren a este como una suma de dinero que se entrega al sacerdote para su mantención previa constatación de su estado de necesidad y carencia de recursos.

${ }^{110}$ DL. (1861), IX, p. 322.

${ }^{111}$ DL. II (1842-1846), II, p. 386. 
ejemplos pues se comprende que la única forma de someter a los aborígenes es mediante la conversión y la evangelización. Es la vía para que acepten al Estado de Chile. Evangelización, civilización y educación en esta época son sinónimos. La expresión política de esta sinonimia, en la problemática mapuche, es que la vieja estrategia de la guerra ofensiva va de la mano con la cristianización.

Por ende, en la década de 1840 se buscó intensamente alguna orden religiosa que quisiera hacerse cargo de las misiones de la Araucanía. Es así como ya en 1844, se encarga al presbítero Cesario González, de la Compañía de Jesús, que busque en Europa a miembros de esa orden que quisieran venir a Chile a hacerse cargo de las misiones abandonadas. Se les ofrece vivir acorde sus constituciones, mas no formar comunidad ${ }^{112}$.

Dichas gestiones no dieron los resultados esperados. La Compañía de Jesús no se interesó por esta propuesta, dado que en Chile no tenía reconocimiento legal y la propuesta al presbítero González no incluía la posibilidad de una reforma legal ${ }^{113}$.

Por ello, el Estado continuó con el esfuerzo pecuniario que estaba realizando, destinado a traer otros misioneros desde Europa, y a fines de la década de 1830 restableció el Colegio de la Propaganda de Chillán ${ }^{114}$ y fundó otro en Castro, los que no dieron los resultados esperados. Sin embargo, constituyen un indicativo de cuán interesado estaba el estado en valerse del clero para poder someter efectivamente a la Araucanía, y que para ello no dudó en valerse de medios propios del mundo indiano, como fue el Colegio de Propaganda de Chillán.

Finalmente, en 1849 los capuchinos se hicieron cargo de las misiones en esas comarcas. Esos religiosos dieron un nuevo enfoque a las misiones. Para evangelizar, propusieron instruir a la juventud aborigen en oficios de carácter técnico, con miras a transformar las misiones en escuelas de artes y oficios. Dicho objetivo necesitaba de los siempre escasos recursos, por lo que el Ejecutivo solicitó a Roma la conmutación del destino de algunas limosnas, para afectarlas a las misiones de la Araucanía ${ }^{115}$. De acuerdo a la memoria del año 1857 , ese año ya había catorce misiones, sostenidas por pocos regulares que hacían su trabajo con gran celo y pobreza. Desgraciadamente, gran parte de ese esfuerzo quedó en nada con la rebelión indígena de 1859, en que fueron incendiadas todas las misiones, excepto la de Nacimiento ${ }^{116}$.

A poco andar esas misiones se recuperaron y se fundaron otras, en diversos puntos de la frontera, como Angol, Nacimiento, Valdivia y Río Bueno, entregando en todas ellas instrucción religiosa a la población mapuche ${ }^{117}$.

El celo y necesidad de servirse de la Iglesia, como la única institución capaz de asumir tareas que el Estado no es capaz de llevar a cabo, motiva al Gobierno

\footnotetext{
${ }^{112}$ Ibíd., p. 265

${ }^{113}$ Ibíd., p. 387

${ }^{114}$ Esta establecimiento, durante la colonia estuvo dirigido a evangelizar y educar a los hijos de los caciques principales de la Araucanía.

${ }^{115}$ DL. (1847-1851), III, p. 291-292

${ }^{116}$ Memoria del Ministro de Justicia, Culto e Instrucción Pública, Año 1864, p. 18

${ }^{117}$ Memoria del Ministro de Justicia, Culto e Instrucción Pública, Año 1865, pp. 30 ss.
} 
a examinar los planes de estudio de las órdenes religiosas y dar su opinión a las congregaciones con miras a futuras reformas en la formación de sacerdotes y religiosos $^{118}$.

Tal interés no es exclusivo de la época en estudio. La memoria del año 1842 señala que una de las dificultades que enfrentó el gobierno durante ese año fue la determinación, acorde con lo dispuesto en el senadoconsulto de 4 de enero de 1819 , quien es la autoridad competente para confirmar los grados otorgados a los miembros de las órdenes regulares. Dicho cuerpo normativo prescribía que tal asunto era competencia del diocesano, lo que generó problemas de interpretación respecto a la vigencia del citado senadoconsulto. Provisoriamente, el Gobierno estipuló que los grados de los regulares fuesen confirmados por una junta de definitorios de las distintas órdenes religiosas, a fin de solucionar el problema inmediato, encargando su resolución definitiva al congreso, al ser materia de ley ${ }^{119}$.

En materia de clero regular, en este período se hace hincapié en la necesidad de fortalecer la disciplina de las congregaciones y reformarlas. Es una constante la preocupación por el estado en que se encontraban la mayoría de las órdenes, cuyo deterioro afectaba al culto en todo el país.

En esa dirección la primera medida adoptada es fiscalizar el cumplimiento de la normativa vigente en cuanto a la edad mínima para ingresar a las congregaciones. Los menores de edad no tenían el suficiente discernimiento para entender lo que significaba ingresar a la vida monacal. Por ello se dictan nuevos decretos, que generaron críticas y oposición. En opinión de los opositores a la medida, dichos decretos atentaban contra la costumbre de aceptar los votos para la vida monacal a los 16 años.

El gobierno respondió en base a la disciplina eclesiástica y a la necesidad de contar con miembros preparados y probos en el culto. Para contar con ministros de culto con esas calidades se requería que la opción por la vida religiosa fuese adoptada por personas maduras, cualidad que el Gobierno no reconoce en personas de 16 años. Para el Gobierno, la mejor manera de resguardar los principios de la religión y no deslegitimarla ante la población es contar con sacerdotes y clérigos preparados y que cumplan los parámetros de conducta que se esperan de los miembros de la Iglesia. No coadyuvaba a lo anterior contar con ministros que después vivieran en un estado de sobresalto al no haber tomado la decisión con los elementos de juicio necesarios ${ }^{120}$.

También en este período surgen conflictos entre las autoridades nacionales y las ordenes monásticas. La situación de estas no estaba regulada en la ley, y por ello el gobierno sostiene que sólo se aceptará su ingreso si está seguro que sirve a la religión y que cumplan con la condición de someterse a las autoridades del país ${ }^{121}$.

${ }^{118}$ DL. I (1831-1841), I, p. 223

${ }^{119}$ DL. II (1842-1846), II, p. 31.

${ }^{120}$ Ibíd., p. 386

${ }^{121}$ El Estado exige respeto a su autoridad y demanda de las congregaciones el cumplimiento del Derecho patrio. Esos fueron los requisitos que se tuvieron presentes a la hora de negociar el retorno de la Compañía de Jesús a Chile, según las fuentes examinadas. 
Otro problema de relevancia jurídica del período en estudio fue el funcionamiento de los archivos parroquiales. En ellos estaban los únicos documentos que daban plena prueba del estado civil de las personas y por ello era gravísimo que muchos clérigos no sabían cómo llevar bien estos archivos o derechamente eran negligentes en su custodia y conservación.

Los párrocos guardaban en ellos todos los documentos jurídicamente relevantes vinculados al Derecho de familia y a la existencia y muerte de las personas, además de guardar declaraciones de voluntad y testimonios importantes, entregados al sacerdote. Por ende, la pérdida de esos libros o su deterioro no era un asunto menor.

Tal problema se solucionó primeramente con la organización de visitas periódicas a los curatos, revisando el trabajo en los archivos, la emisión de un instructivo general y estipular quienes serán los responsables en caso de pérdida, extravío o deterioro de los documentos ${ }^{122}$.

Pero en definitiva, correspondió al arzobispo de Santiago Rafael Valentín Valdivieso, solucionar este vacío legal. Para ello se dictó una ordenanza arzobispal sobre libros parroquiales, se suministró a todas las parroquias libros en número suficiente y con las condiciones requeridas para facilitar su conservación y proteger su autenticidad ${ }^{123}$.

En otro orden de ideas, la progresiva mejora de las relaciones con la Santa Sede también tuvo consecuencias jurídicas. La accidentada visita del ministro plenipotenciario Ramón Luis Irarrázaval, si bien no logró el objetivo del Gobierno, consistente en que Vaticano reconociese el derecho de patronato del Estado sobre la Iglesia chilena, tuvo como consecuencia, algunos cambios en su estructura.

Tales cambios consistieron en que, mediante la figura del arzobispo de Santiago, se autorizó la reforma de las comunidades religiosas, dentro de un plazo de cinco años desde que Roma emitió la autorización.

Del mismo modo, los recursos obtenidos de la bula de cruzada se afectarán al fomento y mantención de las misiones de infieles dentro del territorio nacional y a 1 mantenimiento de los hospitales del archipiélago de Chiloé.

Por último, se autorizó al arzobispo de Santiago para hacer las delegaciones de facultades que estime necesarias a favor del ejército de Chile, entregándoselas a los capellanes y vicarios castrenses.

Cabe señalar que las fuentes trabajadas no vuelven a referirse a este último punto, mas constituye un indicador de hasta qué punto el estado tomo a su cargo responsabilidades que son propias del culto y cuán arraigada estaba en Chile la cultura regalista. Con el avance del siglo, estas facultades estatales perderán progresivamente su legitimidad, quedando sólo amparadas en el respeto a la legalidad. Se desarrollará un espíritu laico entre los hombres de Estado y la Iglesia buscará su independencia y autonomía. Probablemente, en esta materia, la norma legada por el Derecho indiano pervivirá mucho tiempo más que el espíritu regalista. Los cambios normativos vendrán de golpe en el siglo XX con la dictación de una

\footnotetext{
${ }^{122}$ DL. (1847-1851), III, p. 63

${ }^{123}$ DL. (1854-1856), V, p. 97-98.
} 
nueva Constitución. No es posible apreciar en materia de patronato los cambios parciales y detallados que se dieron en otras áreas del Derecho. Al año de 1873, nada ha cambiado todavía, desde un punto de vista jurídico, de lo que el Obispo de Santiago del siglo XVII fray Gaspar de Villarroel tituló como la unión de los dos cuchillos, regio y pontificio, aunque el primero ahora estaba personificado en el presidente de la república, como jefe de Estado.

\section{Instrucción Pública}

Como se decía más arriba, en este período evangelización, educación y civilización son lo mismo. Uno de los grandes empeños del proceso emancipador fue proporcionar un mayor grado de ilustración y luces al pueblo. La erradicación del analfabetismo y la ignorancia será un desvelo constante de todos los gobiernos del período. La educación se entiende como parte de un servicio, en aras del bien común, y como tal constituye un Derecho. La educación es un deber del Estado.

La educación es concebida como la base del sistema republicano de gobierno; como el único medio para reformar la sociedad y como el pilar en el que se basa todo el ordenamiento jurídico.

Este nuevo "Derecho social" tendrá un carácter restrictivo en cuanto a su cobertura; pues el Estado carecía de los medios económicos y humanos para fundar todas las escuelas que el país requería; sin embargo, será una política pública el otorgamiento de becas para que los jóvenes talentosos de provincias puedan ir a estudiar a Santiago, ciudad en la que estaba el Instituto nacional y la Universidad de Chile.

Una meta del Estado es que todas las localidades algún día lleguen a contar con una escuela y que las ciudades cabeceras de provincia cuenten con al menos un liceo. Se busca que la escuela llegue a todos los rincones del país y que penetre en todos los hogares. Se parte de la base que el docente es un agente de cambio social que no sólo instruye a sus alumnos: "La educación primaria no sólo es la educación general de todas las clases del pueblo y por la que deben pasar aun los que se dedican a estudios superiores, sino que es la única que puede adquirir la inmensa mayoría de la Nación, y ella es la que tiene mayor influjo en la moral del pueblo, o la que, por mejor decir, forma las costumbres. Es pues el deber más indispensable del Gobierno difundirla universalmente"124.

Es una constante que año a año se expande el número de escuelas. Es así como con anterioridad a 1839 se habían fundado los liceos de Cauquenes y San Felipe, y se planificaba otro en San Fernando y la reconstrucción de los liceos de Talca y de Concepción y en los años siguientes se menciona la fundación de varias escuelas primarias en distintas partes de la república, llegando a más de 30 en 1844 . Trece años después, la memoria del año 1857 da cuenta de 406 escuelas sostenidas por el gobierno en todo el territorio nacional y en 1865 eran 641.

Así, a poco andar se suman liceos en Valdivia y Rancagua. En 1851 se informa del funcionamiento de nuevas escuelas en Chillán, Linares, Quirihue,

${ }^{124}$ DL. (1839-1841), I, p. 222 
Illapel, Copiapó, Freirina, Vallenar, Calbuco, Nacimiento, Los Andes, Quillota, Putaendo, Elqui y El Monte.

Esta política de Estado fue de largo aliento, pues en todas las memorias queda de manifiesto cuan consiente estaba el gobierno que el primer obstáculo para alfabetizar era la pobreza y la elevada ruralidad del país. La ignorancia generaba vicios como la escasa higiene, con las consecuencias sociales y de salud pública conocidas. Los sucesivos cuentadantes saben que la calidad de la educación impartida no es la que ellos quisieran, ni tampoco que existe la cobertura suficiente para civilizar a esa población. No obstante, no sacrifican ni la calidad ni la cantidad en beneficio de la otra. Se entiende que la falta de educación es causal de pobreza y esta a su vez origen de otros males que distraen recursos públicos como la delincuencia, con el consiguiente gasto del Estado en la construcción de nuevas cárceles.

A fin de dar a estas carencias una solución de largo plazo, el ejecutivo presentó un proyecto de ley el año 1849, denominado "Ley de instrucción primaria", que contemplaba una modificación permanente de la contabilidad estatal, dando un presupuesto separado a educación, apartándolo de la ley periódica de presupuesto nacional. Dejaba en la ley anual de presupuesto los fondos destinados a inspección y escuelas normales.

Los fondos destinados a lo que el citado proyecto denominaba educación popular no sólo provenían del estado, sino de las mismas comunidades, que debían financiar parte de las escuelas. Se pensaba que de esa manera, los habitantes sentirían que la escuela local les pertenece y se involucrarían con ella. Para el cuentadante de esa memoria, Silvestre Ochagavía, era la perfecta simbiosis entre esfuerzo estatal y de la comunidad. De esta forma se acabaría con los dos males que aquejaban al sistema educativo de la república: falta de fondos del Estado para dar la cobertura demandada y la apatía de las comunidades locales, que no sentían las escuelas como propias ${ }^{125}$.

Ese proyecto no tuvo el resultado que el gobierno esperaba, al haberlo presentado en un momento políticamente turbulento.

En consecuencia, el sistema de financiamiento se mantuvo. En el papel, gran parte de las escuelas debían ser financiadas por las municipalidades, más la carestía de recursos de estas, como en otras materias arriba indicadas, llevó a que la construcción y tentación de estas estuviese a cargo de las arcas fiscales.

La calidad de la enseñanza también importaba. Para ello lo primero que se buscó fue homogeneizar los planes y programas, quedando en manos de ese ministerio la adopción del sistema de enseñanza.

La uniformización de los estudios no fue difícil toda vez que todos los colegios financiados de forma total o en parte por las arcas fiscales debían rendir una cuenta anual al ministerio, mediante una memoria en que se señale el funcionamiento de la escuela, clases impartidas, número de alumnos, métodos de enseñanza y recursos con los que se cuenta. Dicha obligación recaía personalmente en el director del establecimiento. La entrega de fondos públicos exigía una rendición de cuentas

${ }^{125}$ DL. ( 1852-1853), IV, p. 322 
no importando la naturaleza jurídica del establecimiento ${ }^{126}$. Las carencias económicas y la permanente escasez de recursos públicos impusieron una cultura de la probidad, el ahorro y la transparencia en el proceso educativo.

Dicha homogenización de los estudios también se hizo mediante la distribución de libros desde el instituto nacional hacia el resto de los colegios secundarios del país. Se busca que todos estudien lo mismo y cada uno de los libros elegidos debía educar el corazón de los hombres.

En otras palabras, este sistema buscó centrarse en la formación moral del alumno. Importa más la moral que la transmisión de conocimientos. Para cumplir ese fin no se consideró necesario que la formación de los docentes estuviese centrada en la naciente Universidad de Chile, sino en las escuelas normales: "El gobierno se propone establecer en Santiago una escuela normal para jóvenes adultos y para aquellos que quieran dedicarse a la enseñanza, en donde aprendan los métodos y los varios ramos que deberá haber en las escuelas que se confien después a su dirección, y en dónde su conducta y principios sean escrupulosamente examinados. De este plantel saldrán maestros dignos de la confianza del público" ${ }^{127}$.

A fin de estimular el trabajo del docente, se instituye una gratificación económica para aquellos que se destacasen, los que iban unidos a un plan de ascenso ${ }^{128}$.

Del mismo modo, se ratifica la necesidad de contar con una institución de excelencia en materia de educación, el Instituto Nacional, y a fin de facilitar el acceso de estudiantes talentosos de otras partes del país, se ofrecen becas y medias becas, las que se destinan de preferencia estudiantes pobres o a huérfanos de funcionarios públicos que han caído en la indigencia.

Las luces de la educación superior republicana no tardaron en hacerse notar, atendido que ya en 1841, es motivo de orgullo para el ministro exponer que las condiciones de estabilidad política y paz en que vive el país han atraído a jóvenes de todas las repúblicas de América a cursar sus estudios superiores.

Sin embargo, el sistema de instrucción pública surgido bajo el imperio de la Constitución de 1833 sólo se verá bien fundado con la creación de la Universidad de Chile. Esta casa de estudios fue concebida como la cabeza del sistema educativo nacional.

Para tal labor, en materia educacional tenía tres grandes potestades: dirección, inspección y jurisdicción educativa. Dirección para monitorear permanentemente su avance, proponer las mejoras necesarias y fomentar el intercambio de experiencias y conocimientos entre el cuerpo académico y las escuelas. Esta facultad se sustrae del ministerio, pues de lo contrario la dirección educativa quedaría sujeta a la contingencia política y a la voluntad del ministro de turno.

La facultad de inspección es inherente a la anterior, y busca ver el cumplimiento de las directrices entregadas, conocer sus defectos y corregirlos y la de jurisdicción comprende la coacción suficiente para que sus disposiciones sean

\footnotetext{
${ }^{126}$ DL. (1842-1846), II, p. 152.

${ }^{127} D L .(1831-1841)$, I, p. 234

${ }^{128}$ DL. (1842-1846), II, p. 155
} 
acatadas, encargándose que los profesores y demás actores responsables cumplan con las obligaciones inherentes a su labor ${ }^{129}$.

Para llevar a cabo tal fin se instauro la figura del visitador educacional, encargado de fiscalizar el cumplimiento de las directrices del ministerio y de la universidad. Los visitadores eran jóvenes preceptores que debían hacer un año adicional de estudios y someterse a exámenes de moralidad, aptitud y carácter ${ }^{130}$.

También en este período se sienta el principio que el ejercicio válido de cualquier profesión científica requiere un grado universitario.

En la década de 1850 también empieza a pensarse en la necesidad de instaurar un sistema de bibliotecas populares. La idea subyacente es que la ignorancia es la base de todos los males de la humanidad, y erradicándose ella, se erradicarán graves problemas sociales que distraen recursos, como la delincuencia y el alcoholismo ${ }^{131}$.

Los resultados de esa política educacional fueron efectivos y muy rápidos. En 1854 ya se habían inaugurado bibliotecas populares, es decir, al servicio de toda la comunidad, en las localidades de Concepción, Ancud, Los Ángeles, Caldera, Valparaíso, Santiago, Vallenar, Freirina, San Fernando, Talca, Constitución, Linares, Cauquenes, Parral, Itata, Coelemu, Talcahuano, Rere, Puchacai, Lautaro, Valdivia y Osorno.

Desgraciadamente, años después se constata que esta iniciativa fue muy prematura para Chile. No había suficiente gente adulta con el hábito bien desarrollado de leer y escribir para gozar de tan noble institución. De hecho, las bibliotecas que más visitantes tienen en el año no pasan de cien, y son las Castro, Achao y Melipulli ${ }^{132}$, por lo que se opta por detener por un período esta iniciativa, limitándose a administrar las que ya hay ${ }^{133}$.

Para financiar estos proyectos se recurrió a los fondos que el erario recibía por concepto de "mandas forzozas"134.

Este impuesto desde su nacimiento tuvo como destino el financiamiento de iniciativas educacionales. Primero financió al Instituto Nacional y cuando este comenzó a recibir aportes directos del Estado, los ingresos por este concepto fueron destinados a los liceos provinciales y en la década de 1850 , comienzan a

${ }^{129}$ Ibíd., p. 266.

${ }^{130}$ DL. IV (1852-1853), IV, p. 326.

${ }^{131}$ Ibíd., p. 325.

${ }^{132}$ Nombre originario de la ciudad de Puerto Montt.

${ }^{133}$ Memoria del Ministro de Justicia, Culto e Instrucción Pública, Año 1865, pp. 49 ss.

${ }^{134} \mathrm{La}$ manda forzosa era un impuesto percibido por las municipalidades y cobrado por los párrocos, para ser invertido en las funciones que les encomendaba la ley. Es un impuesto que grava la sucesión por causa de muerte, que consistía en el pago de \$ 6 por el sólo hecho de emitir un testamento, si la masa hereditaria ascendía a más de $\$ 1.000$, gravando además con $\$ 12$ a todos los herederos forzosos, sin cuyo pago no podían realizar los actos de disposición sobre la masa hereditaria. Este gravamen aumentaba a $\$ 50$ por persona, en caso que el asignatario no fuese legitimario. Cabe señalar que al año 1856 este impuesto carecía de proporcionalidad en su monto. La cantidad a pagar era la misma, no importando a cuanto ascendiera el acervo hereditario, lo que en ese momento es objeto de numerosas críticas. 
proveer de recursos a iniciativas de corte educacional más masivo, como son las llamadas bibliotecas populares ${ }^{135}$.

\section{Consideraciones finales}

El Derecho indiano como sistema jurídico vigente en Chile al momento de comenzar la emancipación tuvo entre sus características ser un Derecho de corte monárquico, estamental, confesional y local. Contemplaba una multiplicidad de fueros y sus más importantes fuentes formales eran la doctrina, la jurisprudencia y la costumbre.

El advenimiento del siglo XIX marca en lo político la fragmentación del imperio hispánico en América y el advenimiento de nuevas repúblicas, que impregnadas de ideales ilustrados, liberales y nacionales, buscan crear su propio Derecho. Se busca la mutación del sistema jurídico, bajo los postulados del constitucionalismo y la codificación.

$\mathrm{Al}$ menos en Chile tal reforma se dio de manera lenta y paulatina. La pervivencia del Derecho indiano impregnó inclusive las constituciones, al estipular bajo terminología liberal, las mismas facultades que antes poseía el monarca, sólo que esta vez tenían su fuente en el papel y no en la costumbre ni en la doctrina.

Sin embargo, fue el progresivo cambio en la mentalidad jurídica y el avance de las ideas del siglo lo que posibilitó a que, por vía de interpretación auténtica, debate legislativo y por reformas jurídicas urgentes y acotadas, se fuese dando forma al Derecho patrio.

Con la excepción del Derecho constitucional, el civil y el mercantil, pareciera que el resto de las disciplinas jurídicas, avanzaron a tientas, entre luces y sombras, resolviendo situaciones concretas, que pavimentaron el camino al Derecho patrio. El ideal codificador fue superado por la realidad. Los grandes principios no esperaron a los códigos; se manifestaron en cada una de las nuevas leyes.

También es importante precisar la clarividencia de los hombres de Derecho de esta época, al constatar que no hay mejor manera de cimentar las instituciones que cambiando la mentalidad de la población y la solucionando sus necesidades jurídicas concretas. En ella se fundamentó el respeto al Derecho y el sentido legalista del país.

Para esos efectos, fue importante el énfasis dado a la adquisición de bibliotecas jurídicas, la permanente revisión de las mallas curriculares en la Facultad de Derecho y el espíritu crítico sobre el sistema jurídico.

Asimismo, el Estado de Chile tendrá como gran objetivo un ideal muy propio de la ilustración: la educación y civilización de las masas. La razón hará feliz a la mayoría de los hombres, y para alcanzar ese objetivo, se vale de dos medios importantísimos: la escuela y la Iglesia. Mediante la primera se difunden las luces del siglo y se pretende formar personas aptas para asumir liderazgos que exceden por mucho el ámbito propio del aula. Se quiere profesores cuyo corazón esté educado y no que detenten conocimientos acabados de lo que van a enseñar

${ }^{135}$ DL. (1854-1856), V, p. 357. 
La Iglesia será la otra gran moralizadora, mediante la instrucción en los misterios de la fe y la administración de los sacramentos. En esta época aun no es aceptada la posibilidad de una moral separada de la religión.

El naciente estado se sirve de ella y la mantiene. Se da una suerte de contrato callado o tácito entre ambos poderes. Es un consenso de esa sociedad la necesidad de contar con una Iglesia fuerte y con un ámbito de competencia enorme.

Por último, cabe rescatar la mirada de largo plazo de los hombres de esta época. Mientras parte importante de las bases ideológicas del Derecho vigente se darán en un período anterior al estudiado, llegando inclusive a concretar reformas pendientes del pasado colonial, es en las primeras memorias del período donde se explicitan los principios e ideas rectoras de los años estudiados. Mientras en los primeros años de la década de 1840 hay principios e ideas jurídicas de alto vuelo, en los años posteriores se van detallando las dificultades de la implementación de esas ideas. La mayor riqueza desde la teoría del Derecho está en los primeros diez años.

Por tal razón, volvemos a insistir en la necesidad de estudiar el Derecho patrio desde lo particular a lo general, ahondando en las reformas legislativas aparentemente menores más que centrarnos en los ya abundante y magistralmente estudiados códigos.

\section{BiBLIOGRAFÍA}

Actas oficiales de las sesiones celebradas por la comisión y subcomisión encargadas del estudio del proyecto de nueva Constitución Política de la república (Santiago, Ministerio del Interior, Imprenta Universitaria, 1925).

AnguiTa, Ricardo, Leyes promulgadas en Chile (Santiago, Imprenta, Litografía y Encuadernación Barcelona, 1912), II: 1855-1886.

Barrientos Grandón, Javier, La Constitución de Cádiz en Chile, en Escudero, José Antonio (coordinador), Cortes y Constitución de Cádiz 200 años (Madrid, Fundación Rafael del Pino, Espasa Libros, 2011), III.

Carrasco Delgado, Sergio, Alessandri, su pensamiento constitucional: reseña de su vida pública (Santiago, Editorial Jurídica de Chile, 1987).

De Mora, José Joaquín, Curso de Derecho en el Liceo de Chile: Derecho naturaly Derecho de Jentes. (Santiago, Imprenta Republicana, 1830).

Documentos Parlamentarios (= DP.) (Santiago, Imprenta del Ferrocarril, 18391861).

Dougnac, Antonio, Del Derecho indiano al patrio: el tránsito del magistrado Juan de Dios Vial del Río (1774-1850), en Revista Chilena de Historia del Derecho, 19 (2003-2004).

Egaña, Juan, Cartas Pehuenches (Santiago, Lom Ediciones, 2001).

GuZmán Brito, Alejandro, El vocabulario para la idea de Constitución Política, en Revista de Estudios Histórico-Jurídicos, 24 (2002).

GuZmán Brito, Alejandro, La enseñanza del Derecho. Historia y perspectivas, en Anales del Instituto de Chile, 25: Estudios II: La educación superior en Chile (Santiago, 2005-2006). 
Heisse GonzÁlez, Julio, Historia de Chile: el periodo parlamentario, 1861-1925 (Santiago, Andrés Bello, 1974-1982), 2 volúmenes.

LeVAGGi, Abelardo, La Constitución chilena de 1833 como modelo del presidencialismo argentino, en Libro de amigos dedicado al profesor emérito Italo Merello (Valparaíso, Ediciones Universitarias de Valparaíso, 2011).

Memoria del ministro de Justicia, Culto e Instrucción Pública Años 1864, 1865, 1866, 1867,1868 y 1873.

Merello Arecco, Italo, La ley mariana de fundamentación de sentencias frente a la clemencia judicial en materia penal, en Revista de Estudios Histórico-Jurídicos, 8 (1983).

Westermeyer Hernández, Felipe, Notas para un estudio de la evolución de la judicatura en Revista de Derecho y Humanidades, 9 (2002-2003). 
